\title{
FRAGMENTED PROPERTY SYSTEMS
}

\author{
DANIEL FITZPATRICK*
}

\begin{abstract}
This article considers fragmented property systems - the phenomenon of contested, separated or overlapping sub-systems within a national property jurisdiction. One example is circumstances of property despite law. Globally, as many as a billion people claim de facto property without recognition by law in urban informal settlements and agro-pastoral or forested areas. Another example is property without transition to law. Many households in the developing world regulate land markets through local mechanisms notwithstanding opportunities or requirements to use law. The article provides a conceptual frame for the emergence of property system fragmentation based on the private coordination of property relations. The article argues that fragmentation emerges in complex property systems where law attempts to displace property coordination mechanisms, but fails to induce a critical mass of property participants to alter coordination strategies. A focus on coordination provides a means to combine the methodological individualism of economic narratives with collective variables highlighted by other perspectives on property such as anthropology and complex sys-

* Professor Daniel Fitzpatrick, BA LLB LLM PhD, ANU College of Law, Australian National University. Much of the article was written while a Global Senior Visiting Research Fellow at New York University School of Law, Hauser Global Law Program (Fall Semester 2014). I am grateful for comments from Omri BenShahar, Abraham Bell, Nestor Davidson, Kevin Davis, Lewis Kornhauser, Ethan Leib, Frank Upham, Katrina Wyman, and participants at the Yale University School of Forestry and Environmental Studies Environmental Law Seminar, the New York University School of Law Global Fellows Forum, and the Fordham University Law School Faculty Workshop. I am grateful for Future Fellowship funding assistance from the Australian Research Council (FT110101065).
\end{abstract}


[Vol. 38:1

tems theory. 


\section{TABLE OF CONTENTS}

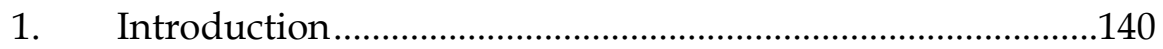

2. The Phenomenon of Fragmented Property Systems .............144

2.1. Property Without Law: Slums, Forests and Agriculture ......144

2.2. Property at Scale: Localized Entitlements ..............................150

2.3. Formalizing Property: Mixed Results for Land Titling .........152

2.4. Hybrid Documents and Fragmented Land Markets ..............154

2.5. Property Despite Law .......................................................157

2.6. The Politics of Fragmentation ............................................158

2.7. The Limits of Cost/Benefit Analysis ......................................163

3. A Conceptual Frame for Property System

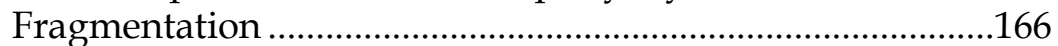

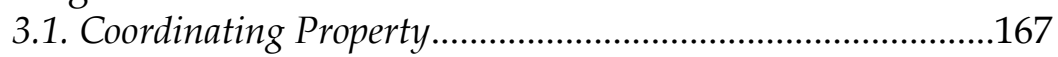

3.2. Possession and Law ..............................................................170

3.2.1. Complex Possession in East Timor ...........................173

3.3. Custom and Law.................................................................176

3.3.1. The Embeddedness of Custom in Kenya ....................178

3.4. Transitions to Law .............................................................183

3.4.1. State Title to Land in Cambodia ................................185

3.5. The Paths of Property Systems .............................................191

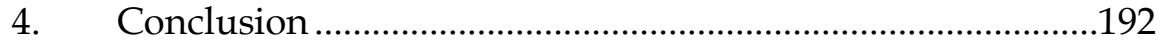




\section{INTRODUCTION}

There are two basic economic accounts of property transitions: Demsetzian and public choice. ${ }^{1}$ Demsetzian narratives analyze the cost/benefit calculations of resource users. ${ }^{2}$ Property crystallizes as a response to the benefits of exclusion and the costs of open access. This is an optimistic view of the evolution of property as a product of changed economic circumstances. ${ }^{3}$ In contrast, public choice narratives describe property transitions through the exercise of political power.4 Unless there are countervailing political pressures, individuals who hold political power will choose property rules, and allocate property rights, to maximize their own benefits rather than the welfare of the society as a whole. ${ }^{5}$ This is a skeptical or pessi-

1 See Saul Levmore, Property's Uneasy Path and Expanding Future, 70 U. CHI. L. REV. 181 (2003) (observing that for every efficiency-based explanation "there is an alternative and skeptical view that is interest group, or politically, driven"); Richard A. Epstein, The Allocation of the Commons: Parking on Public Roads, 31 J. LEGAL STUD. S515, S543-44 (2002) ("Demsetz's basic efficiency story is tempered with a healthy dose of public choice theory"). James Krier makes a related distinction between autonomous and intentional design accounts of the origins of property. See James E. Krier, Evolutionary Theory and the Origin of Property Rights, 95 CORNELL L. REV. 139, 151 (2009) (discussing the various accounts of the origins of the social practice of individual ownership); see also ROBERT C. ELLICKSON, ORDER WITHOUT LAW: How NeIghbORS SETTLE Disputes 137-40 (1991) (discussing property in terms of distinctions between legal centralism and property without law) [hereinafter ELLICKSON, ORDER WITHOUT LAW]; see generally Saul Levmore, Two Stories About the Evolution of Property Rights, 31 J. LEGAL STUD. S421 (2002) (providing an overview of Demsetzian and public choice accounts).

${ }^{2}$ See Armen A. Alchian \& Harold Demsetz, The Property Right Paradigm, 33 J. ECON. Hist. 16, 25 (1973) (providing applications of Demsetz's thesis and discussing the enclosure movement in twelfth-and thirteenth-century England); see also Ester Boserup, THE CONDITIONS OF AgriculturAl GROWTH: THE ECONOMICS OF Agrarian Change Under Population Pressure (1965); Yujiro Hayami \& Masao KiKUCHI, Asian Village Economy at the Crossroads: An ECONOMIC APPROACH to Institutional Change (1981); see generally Harold Demsetz, Toward a Theory of Property Rights, 57 Am. ECON. ReV. (PAPERS \& PROC.) 347 (1967).

3 See Levmore, supra note 1, at 182 ("The Demsetz-style story... is at root quite optimistic").

4 See Stuart Banner, Transitions Between Property Regimes, 31 J. LeGal STUD. S359, S361 (2002) (stating that political action and changes in property regimes moved towards efficiency); see also, ITAI SENED, THE POLITICAL Institution of PRIVATE PROPERTY (1997), at 33-50 (ascribing evolution of property to political institutions); Katrina Miriam Wyman, From Fur to Fish: Reconsidering the Evolution of Private Property, 80 N.Y.U. L. REV. 117 (2005) (discussing politics of property rights in US fisheries).

5 See Daron Acemoglu, Simon Johnson \& James A. Robinson, Institutions as a Fundamental Cause of Long-Run Growth, 1 HANDBOOK ECON. GROWTH 368, 427 
mistic view of property transitions that may involve the exclusion of Demsetzian claimants. ${ }^{6}$

Optimistic Demsetzian accounts appear simplistic when tested against the reality of property informality in many parts of the world today. ${ }^{7}$ Almost a billion people live in urban settlements on land legally owned by others. ${ }^{8}$ Hundreds of millions live on land claimed by the state in agricultural, pastoral and forested areas. ${ }^{9}$ Many claim property despite law - a fact illustrated by long-term acts of residence, use and exclusion. Even for households with de jure rights to land, a remarkable number - as much as $80 \%$ in some jurisdictions - continues to regulate transfers of land through substate processes even though law mandates registration of title transfers in a national cadastral system. ${ }^{10}$ All these cases manifest the evolution of property through a broad fragmentation of de facto and de jure property sub-systems. State actors have a limited capacity to enforce de jure rules or rights against de facto property claims; de facto claimants are engaging in various strategies of resistance to legal rules or de jure rights; and significant numbers of de jure claimants follow de facto methods of land administration.

On its face, the phenomenon of fragmented de jure and de facto property systems has a simple public choice explanation. Political incentives may produce laws that deny de jure recognition to large numbers of occupiers or users of land. Because state actors may accrue private benefits from the allocation of de jure property rights, without incurring private costs of enforcement, there are incentives to allocate de jure rights to persons other than local Demsetzian claimants. ${ }^{11}$ Yet, while public choice analysis may explain

(2005) (“[E]conomic institutions that enforce property rights or protect against state predation may not be in the interest of a ruler who wants to appropriate assets") [hereinafter "Acemoglu et al., Institutions"].

6 See Levmore, supra note 1, at S423 (stating the public choice story "is about interest groups and is potentially pessimistic").

7 See, e.g., Daniel Fitzpatrick, Evolution and Chaos in Property Rights Systems: The Third World Tragedy of Contested Access, 115 Yale L. J. 996 (2006) (arguing that the Demsetz thesis does not explain chronic Third World property contests); see also Klaus Deininger, WORLd BANK, LAND POlicies fOR GROWTH AND POVERTy REDUCTION 9 (2003) ("[T]here are many cases where the virtuous cycle of increased scarcity of land leading to more precise definition of property rights has not materialized, but instead conflict has arisen.")

8 See infra Section 2.1 .

9 See infra Section 2 (providing examples).

10 See infra Section 2.1.

11 See Lee J. Alston et al, The Development of Property Rights on Frontiers: En- 
the legal exclusion of Demsetzian claims, it does not explain responses to law by Demsetzian claimants. Why do some Demsetzian claimants choose to resist or ignore law? In what circumstances do Demsetzian claimants submit to law, even where the law denies their property claims? How and why do Demsetzian claims persist notwithstanding law? While public choice narratives provide a framework to analyze the political design of property rules, they do not provide a comprehensive account of responses to rules-the everyday acts of resistance, ignorance or accommodation that help to constitute a complex, multi-scale property system.

This article develops a conceptual frame for the emergence of property system fragmentation that moves beyond Demsetzian and public choice narratives of property transitions. Property systems are not fragmented where a critical mass of people coordinates property relations directly or indirectly on the basis of law, either because law provides space for private coordination mechanisms, or because law induces or facilitates alterations in private strategies of property coordination. Conversely, property system fragmentation emerges where law attempts to displace or standardize private coordination mechanisms, but a critical mass chooses to retain prior coordination strategies. The implication is that critical mass responses to law are a key variable in the evolution of property systems. If a critical mass of Demsetzian claimants were to submit or resort to property law, there would be little or no fragmentation of de facto and de jure property sub-systems. Proprietary claimants would coordinate expectations of respect for property either on the basis of law, or on the basis of coordination mechanisms recognized by law. However, if Demsetzian claimants choose not to submit or resort to law, and law attempts but fails to displace their systems of property coordination, the consequence is chronic fragmentation of de facto and de jure property sub-systems so long as (1) the state is not willing or able to enforce law, and (2) transaction costs prevent agreements among de facto and de jure property claimants.

A focus on coordinating property relations highlights the need for conceptual approaches to property system fragmentation that encompass not only individual decision-making but also collective processes of social organization. ${ }^{12}$ The methodological individual-

dowments, Norms and Politics, 72 J. OF ECON. HIST. 741, 750 (2012) (showing that in all of the cases de jure property rights were granted without enforcement mechanisms in place).

12 See Katharina Pistor, Contesting Property Rights: Towards an Integrated Theory 
ism of economic analysis provides a means to analyze decisions that prefer alternative coordination arrangements to law (and vice versa). However, coordination also requires techniques of legitimation - the use of ritual, symbolism and myth to maintain the social basis for expectations of coordinated behavior. Coordination implicates the epistemology of property - the understanding of acts such as possession or the legitimacy of law. Coordination takes place at different scales of interaction-within and across systems of family, group and state ordering. Coordination may even involve distinct sub-systems with their own imperatives and processes for selforganization. In all these senses, complex problems such as property system fragmentation require macro-analytical frames beyond the cost/benefit calculations of individual actors. ${ }^{13}$ Under a broad rubric of coordination analysis, therefore, this article identifies ways in which insights derived from anthropology and complex systems theory may replace, supplement or modify the methodological individualism of economic explanations for fragmented property systems.

The article proceeds as follows. Part 2 begins by describing property system fragmentation in the developing world. The focus is property in land. The contemporary reality of many developing countries is not Demsetzian evolution to well-defined private property, but a broad bifurcation of de jure and de facto property subsystems relating to land. Part I then argues that neither a Demsetzian focus on incentives to claim or delineate property, nor a public choice focus on the political design of property rules, explains the emergence of chronic property system fragmentation. Part 3 sets out case studies of property system fragmentation from East Timor, Kenya and Cambodia. The case studies generate the premise that property system fragmentation develops when law attempts to displace private coordination mechanisms, but fails to induce a critical

of Institutional and System Change, 11(2) GLOBAL JURIST 2 (2011) (arguing that the micro-perspectives of new institutional economics do not explain adequately macro-aspects of contests among property rights).

13 As with other types of "wicked problems", the phenomenon of property system fragmentation involves issues of scale, persistence and complexity that militate against mono-disciplinary perspectives. See Horst W. J. Rittel \& Melvin M. Webber, Dilemmas in a General Theory of Planning, 4 POL'Y SCI. 155, 160-69 (1973) (introducing multi-faceted concept of wicked problems); see also JeFF CONKLIN, DiAlOgUE MAPPING: BUILDING SHARED UNDERSTANDING OF Wicked PROBLEMs 3-40 (John Wiley \& Sons Ltd. eds., 2006) (discussing trans-disciplinary approaches to wicked problems). 
mass of property participants to alter coordination strategies. Whether or not a critical mass of citizens adopts law as a basis for property coordination turns on a range of variables, not only individual calculations of the costs and benefits of law, but also collective processes of social organization. The analysis provides insights into the comparative paths of property systems. The article concludes with comments on the implications of property system fragmentation for the design of law.

\section{THE PHENOMENON OF FRAGMENTED PROPERTY SYSTEMS}

\subsection{Property Without Law: Slums, Forests and Agriculture}

There is a global phenomenon of fragmented property systems. In 2012, around 862,000 people lived in urban informal settlements. ${ }^{14}$ Typically, the state or private parties have legal ownership of their land. Yet, while there are many cases of forced evictions, many others involve long-term acts of occupation notwithstanding law. ${ }^{15}$ For example, a survey of Kolkata, India, in 2003 found that over $40 \%$ of slum residents had occupied their land for two generations or more. ${ }^{16}$ Similarly, in rural areas there are estimates that at least a billion people lack secure rights to land. ${ }^{17}$ Many, if not most,

14 See United Nations Human Settlements Programme, State of the WORLD'S CITIES 2012/2013: PROSPERITY OF CITIES 151 (2013); see also U.N. SecretaryGeneral, Road Map towards the Implementation of the United Nations Millennium Declaration, Rep. of the Secretary-General, U.N. Doc. A/56/326 (Sept. 6, 2001) (describing a Millennium Development Goal target of improving the lives of slum dwellers inter alia through security of land tenure).

U.N. INTER-AGENCY EXPERT AND ADVISORY GROUP ON MDG INDICATORS, MillenNiUm Development GoAls IndicAtors (2002) (establishing a Millennium Development Goal of improving the lives of slum dwellers through security of land tenure).

15 See United Nations Human Settlements Programme \& United Nations ECONOMIC AND SOCIAL COMmission fOR the Asia-PAcific, THE STATE OF Asian CITIES 2010/11, 126, 162 (2010) (stating that UN-HABITAT provides an estimate of $2,090,772$ cases of evictions in 2005 alone). While in absolute terms this figure is very large indeed, it is relatively small compared to the total number of informal landholders in the world today.

16 United Nations Human Settlements Programme, The Challenge of SLUMS: GLOBAL REPORT ON HUMAN SETTLEMENTS 213 (2003).

17 See Roy L. Prosterman, Robert Mitchell \& Tim Hanstad, One Billion 
live in areas claimed as state forest land or, more recently, as state land that is subject to large-scale grants to agribusiness interests. Yet here too many rural residents are not subject to eviction, or other forms of enforcement of law, while claiming rights to land on the basis of generational use or occupation, or purchase through informal land markets. ${ }^{18}$ Thus, the global phenomenon of property informality is also a puzzle of property despite law - where those that the state classifies as "squatters" still engage in property-like activity. The following Part provides examples from urban, forest and agrarian areas of the developing world.

Urban informal settlements may develop where a de jure landowner enters into agreements to provide housing on land, but there is no de jure recognition of the property rights of householders due to a lack of permission for the subdivision, or violations of zoning, planning or construction rules. ${ }^{19}$ The householders hold personal rights against the landowner, but may have no lawful proprietary interests in the land. Alternatively, the informal settlement develops through construction of houses on vacant land without permission from the owner of the land, such that the householders have no de jure rights to the land at all. ${ }^{20}$ In both cases, there is evidence that many, if not most, households develop expectations of proprietary or property-like entitlements, even in circumstances where they acknowledge the formal illegality of their claims. ${ }^{21}$ One example is a study of informal urban settlements in Bandung, Indonesia, where $76.4 \%$ of respondents who identified their landholding as illegal also stated there was no possibility of eviction by the government, with $36.8 \%$ claiming the basis for their perceptions of property as long-term occupation, and a further $47.2 \%$ identifying their possession of documentation evidencing residence on land (e.g. utility bills, land tax receipts, sales contracts or letters from local govern-

\footnotetext{
Rising: LAW, LAND AND THE AlLEVIATION OF GLOBAL POVERTY (2009).

18 Id. at 6-8.

19 See Geoffrey Payne \& Alain Durand-Lasserve, Holding On: Security of Tenure-Types, Policies, Practices and Challenges, RESEARCH PAPER PREPARED FOR THE SPECIAL RAPPORTEUR ON ADEQUATE HOUSING AS A COMPONENT OF THE RIGHT TO AN ADEQUATE STANDARD OF LIVING, AND ON THE RIGHT TO NON-DISCRIMINATION IN THIS CONTEXT 17 (2012) (discussing different types of settlement typologies).

20 Id. at 17.

21 See UN-HABITAT, CHALLENGE Of SLUMS, supra note 16, at 60; see generally A. Durand-Lasserve, Informal Settlements and the MDGs: Global Policy Debates on Property Ownership and Security of Tenure, GLOBAL URBAn DeVELOPMENT MAGAZINE, Mar., 2006, at1.
} 
ment officials). ${ }^{22}$ In Indonesia, these documents operate as a mechanism to coordinate property transfers, even though they are not necessarily recognized as evidence of rights in law. ${ }^{23}$

Tropical forests provide a similar story of divergence between de jure rules and de facto property claims to land. Based on a survey of 52 countries, the Rights and Resources Institute estimates that $73 \%$ of the global forest area is classified as forest land administered by governments. ${ }^{24}$ Aside from protected forest reserves, most government-administered forests are legally subject to concessions granted to commercial forestry or agribusiness interests. ${ }^{25}$ Only $14.5 \%$ of the global forest area is owned by, or designated for, local communities and indigenous peoples. ${ }^{26}$ Yet, while global figures are unavailable, there is little doubt that local communities and indigenous peoples habitually occupy or use much more than $14.5 \%$ of the global forest area without de jure recognition of proprietary claims. $^{27}$ For example, Indonesia's 1967 Basic Forestry Law classi-

22 See GustaAf ReERINK, Tenure Security for IndONESia's Urban PoOR: A SOCIO-LEgAl STUDY ON LAND, DECENTRALISATION AND THE RULE OF LAW IN BANDUNG, 216-17 (2011).

23 See Raymond J. StruyK, Michael L. Hoffman \& Harold M. Katsura, The MARKET FOR SHELTER IN INDONESIAN CITIES 93-95 (1990) (discussing different types of ad-hoc property documents used in Indonesia).

24 See WAshington D.C.: Rights and Resources Initiative, What Future FOR REFORM? PROGRESS AND SLOWDOWN IN FOREST TENURE REFORM SINCE 2002, 16-17 (2014) (defining "land administered by governments" to include all land that is legally claimed as exclusively belonging to the state, areas where community rights are limited to basic access or withdrawal rights that can be extinguished legally with relative ease by the state, and forest land awarded under concessions where the state retains legal ownership).

25 Id. at 17.

26 Id. at 17 (showing that around $11.5 \%$ of the global forest area is legally owned by private individuals and corporations).

27 See, e.g., Peter Dorner \& William C. Thiesenhusen, Land Tenure and Deforestation: Interactions and Environmental Implications (U.N. Research Inst. for Soc. Dev., Discussion Paper No. 34, 1992) (demonstrating that proxy evidence may be found in the broad literature on forest conflicts between local groups and state agencies); see generally Robert Mendelsohn, Property Rights and Tropical Deforestation, 46 OXFORD ECON. PAPERS 750 (1994). For more specific regional studies, see CONFlict over Natural Resources IN SOUTH-EAST Asia AND THE PACIFIC (Lim Teck Ghee \& Mark J. Valencia eds., 1990) (focusing on the Pacific and South-East Asia region); see also OWEN J. LYNCH \& KIRK TALBOTT, BALANCING Acts: COMMUNITY-BASED Forest MANAGEMENT AND NATIONAL LAW IN ASIA AND THE PACIFIC (Marshali S. Berdan ed.,1995) (focusing on the greater Asia region); CENTER FOR INTERNATIONAl Forestry RESEARCH, Municipal Forest MANAGEMENT IN LATIN AMERICA (Lyès Ferroukhi ed., 2003) (focusing on the South America and Caribbean region). 
fied almost $70 \%$ of the archipelago as state forest land. ${ }^{28}$ Estimates of the numbers of long-term residents of state forest areas range from 35 to 90 million. Estimates of the number of people living in forest areas allocated to private concession-holders range from 40 to 60 million people. ${ }^{29}$ Similarly, in Thailand, as many as 15 million people live without de jure rights in state forest areas that cover $45 \%$ of the land mass of Thailand. ${ }^{30}$ In both Indonesia and Thailand there are reports of widespread forest conflicts and contests over attempts at enforcement of law by the state or concessionaires. ${ }^{31}$ However, there are also very large numbers of long-term occupiers of state forest land that have not been subjected to attempts at eviction. Many of these landholders also appear to have Demsetzian perceptions of property entitlements that go beyond mere licenses to occupy, revocable at will by the state. Yet, they too lack the benefit of de jure recognition of their claims.

As to agricultural areas, the NGO Grain estimates on the basis of national census data that small farms hold less than $25 \%$ of the world's farmland, even though they constitute over $90 \%$ of all farms worldwide. ${ }^{32}$ The balance is lawfully held either by corporate

28 Basic Forestry Law, 5/1967, Art. 5 (Indon.); see also MARCUS COLCHESTER ET AL, THE APPLICATION OF FSC PRINCIPLES 2 \& 3 IN INDONESIA: OBSTACles AND POSSIBILITIES 10-25 (2003) (describing the way in which the Indonesian government relied on the state's right to control land to classify most of the archipelago as state forest land).

29 ARnAldo CONTRERAs-Hermisilla, Forest TrEnds \& ChIP FAy, Strengthening Forest MANAgEment in IndOnesia Through LAND Tenure REFORM: ISSUES AND FRAMEWORK FOR ACTION 16 (2005).

30 See generally Jason Lubanski, Land is Life: A Policy Advocacy Case Study of the Northern Thailand Land Reform Movement 15 (Capstone Collection, Paper 2565, 2012) (citing Editorial, Setting out to Replant Forests, BANGKOK POST, March 2, 2012; XAVIER GINE, WORLD BANK, LAND SECURITY IN RURAL THAILAND: EVIDENCE FROM A PROPERTY RigHTS REFORM 4 (2005); see also USAID, THAILAND: PROPERTY RightS AND Resource Governance Profile 10 (2010) (estimating that 12 million people live in Thailand's forests); Jeanette Clarke, Trends in Forest Ownership, Forest Resource Tenure and Institutional Arrangements: Are They Contributing to Better Forest Management and Poverty Reduction? (FAO, Forestry Policy and Institutions Working Paper No. 14, 12, 2006) (providing an estimate of 1.3 million households in declared forest areas - the majority of which live in conservation forests).

31 See J.Y. CAMPBEll, Differing PERSPECTIVES ON COMMUNITY FORESTRY IN INDONESIA, IN WHICH WAY ForWARd? PEOPLE, Forests, AND POliCYMAKING IN INDONESIA 110-25 (C.J.P. Colfer \& I.A.P. Resosudarmo eds., 2002); see also JoHN F. MCCARTHY, DECENTRALIZATION, LOCAL COMMUNITIES AND FOREST MANAGEMENT IN Barito Selatan District, Central Kalimantan (2001); Gine, supra note 30, at 4; USAID, supra note 30 , at 10 .

32 See Grain, Hungry FOR LAND: SMAll FARMERS FeEd the WORLD With LeSS THAN A QUARTER OF ALl FARMLAND 5-6 (2014) (providing an in-depth look into 
interests or directly by the state itself. In Africa, almost $90 \%$ of all farms are family-owned, but family farms have legal rights to less than $15 \%$ of total farmland. ${ }^{33}$ Grain comments that small farms in Africa are probably using much more than $15 \%$ of total farmland as national census data do not include landholdings in areas designated as state-owned or land lawfully owned by others. ${ }^{34}$ There is also a well-documented trend away from legal recognition of ownership of land by family farms as a result of increased global demand for food and agribusiness products. ${ }^{35}$ Since the 1960s, approximately $140,000,000$ ha of land - an area equivalent to the total farmland of the European Union - has been transferred to commercial soy bean, oil palm, rape seed and sugarcane plantations. ${ }^{36}$ The World Bank identifies grants of concessions or ownership of around 56,000,000 ha of farmland for large-scale agribusiness projects between 2008 and 2010.37 More than half were in Africa, with grants from 2004 to 2009 of 3,965,000 ha in Sudan and 2,670,000 ha in Mozambique alone. ${ }^{38}$ At the same time, the World Bank estimates around $21 \%$ of announced large-scale agricultural deals from 2008 to 2011 had not commenced cultivation. ${ }^{39}$

There are no global figures on the numbers of people living on land granted to large-scale agribusiness concerns. The number and scale of agribusiness grants that have not commenced production, or overlap with areas of community land, suggest that considerable numbers remain on land notwithstanding the allocation of de jure property rights to another person or entity. ${ }^{40}$ For example, there are

small farmers and their decreasing proportional share of farmland); see also SARAH K. LoWder, JaKOb SKOet \& SAumya Singh, What Do We Really KNOW AbOut the NUMBER AND DISTRIBUTION OF FARMS AND FAMILY FARMS IN THE WORLD? 8 (2014) (showing another estimate is that family farms constitute $70 \%$ of the world's farms).

33 GRAIN, supra note 32, at 6-7.

34 Id. at 7.

35 Id. at 10. See also LORENZO COTUla, LAND 'GRABBING' IN THE SHADOW OF THE LAW: LegAL FRAMEWORKS REgULATING THE GLOBAL LAND RuSH, reprinted in THE Challenge OF FoOd Security: International Policy and Regulatory FRAMEWORKS (Rosemary Rayfuse and Nicole Weisfelt eds., 2012).

36 GRAIN, supra note 32, at 9.

37 Klaus Deininger et Al., Rising Global InTERest in Farmland: CAN It Yield SuSTAINABLE AND EQUiTABLE BenEFITS? XIV, XXXII (2011).

38 Id. at XXXIII; Id. at XXXII (stating that approximately two-thirds of all large-scale agricultural land grants were in Africa alone).

39 Id. at XIV.

$40 I d$. at 63 (" $[\mathrm{I}] \mathrm{n}$ many of the cases studied, investors acquired land in quanti- 
estimates that production has not commenced on around 12 million ha of land allocated worldwide to oil palm interests. ${ }^{41}$ In Mozambique, a 2009 audit concluded that $34 \%$ of all agribusiness projects had not commenced production. 42 In Sudan, agribusiness land grabs reportedly encompassed entire villages. ${ }^{43}$ In Zambia, survey data indicate that land granted for agribusiness projects overlaps significantly with areas used for shifting cultivation. ${ }^{44}$ In Mozambique, there are over 418 cases covering 1.4 million hectares of land where grants to investors overlap with areas delimited as community land. ${ }^{45}$ On the basis of regression analysis, the World Bank identifies a correlation between poor quality recognition of rural rights to land and the attractiveness of a jurisdiction for large-scale agribusiness projects. ${ }^{46}$ In all cases, poor quality cadastral data exacerbate the potential for overlaps between de facto and de jure claims to land. ${ }^{47}$

ties much larger than they could use, at least initially."); see also id. at 98 ("In almost all cases, land... targeted for investment is subject to... overlapping rights held by communities, individuals, [or] the state.").

41 Id. at 20-21 (citing Joseph Fargione, et al., Land Clearing and the Biofuel Carbon Debt, 319 ScI. 1235, 1235-38 (2008)).

42 Id. at 62 (discussing a land audit taken from a sample of projects); see also A. LOCKE, ECONOMIC AND FINANCIAL ANALYSIS OF LARGE-SCALE LAND ACQUISITION for Agricultural Production in MozambiQue (2009) (discussing the effect of large-scale land acquisitions on food security and poverty).

43 DeININGER, supra note 37, at 60 (discussing the effect of having "limited attention to identifying existing rights" in Sudan).

$44 \mathrm{Id}$. at 61 (discussing the consequence of schematically drawing boundaries); see also WORLD BANK, AWAKENING AFRICA's SLEEPING GIANT: PROSPECTS FOR Competitive Commercial Agriculture in the Guinea SAVANnAH ZONE AND BEYOND (2009) (analyzing the feasibility of using the identification of products and production systems to increase commercial agricultural competitiveness).

45 The number of overlapping or contested land tenure cases in Mozambique may be substantially higher as only $12 \%$ of all communities have received formal delimitation of their legal title to land. See DEININGER, supra note 37, at 61; see also LOCKE, supra note 42, at 25 (discussing the reasons why it is problematic that land under formalized DUATS was considered as not potentially available in a zoning exercise).

46 DEININGER, supra note 37, at 55 (correlating negative rural land recognition with the percentage of implemented projects).

$47 I d$. at 58-60, 117 (illustrating the challenges with collecting inventory data). 
[Vol. 38:1

\subsection{Property at Scale: Localized Entitlements}

Demsetzian property claims may not receive recognition from the state, but they may benefit from acknowledgement at local scales of governance. Local acknowledgement helps to transform a property claim into de facto property (or quasi-property)involving third-party perceptions of proprietary entitlement notwithstanding a lack of recognition by law. ${ }^{48}$ Even in the absence of de jure entitlements, there is evidence that property-like claims supported by localized governance mechanisms may provide sufficient perceptions of security from appropriation or encroachment for investments in available forms of technology. ${ }^{49}$ For example, a number of studies of customary tenure find correlations between community-acknowledged proprietary entitlements to land and investment in observable land improvements, including building houses, planting economic trees or crops, applying fertilizer, destumping and terracing, and fencing off plots. ${ }^{50}$ In Ghana, there was no difference in investment outcomes for land subject to land

48 See Jeremy Bentham, The Theory of Legislation 113 (C.K. Ogden ed. Richard Hildreth trans., 1931 [1802]) ("Property and law are born together, and die together. Before laws were made there was no property; take away laws, and property ceases"). This type of law-centric conception of property implies that at most local recognition of proprietary entitlements creates quasi-property or property-like effects. While implicitly disputing the legal centralist view that denies the possibility of property without law, this article does not necessarily require definitive conclusion as to the definitional scope of property and its relationship with law as it focuses on fragmentation - the phenomenon of chronic contests, overlaps or disconnections involving proprietary claims. The question of whether to describe locally acknowledged property claims as quasi-property or property does not remove the core question of how chronic property system fragmentation develops.

49 DEININGER, supra note 7, at 52-53 (discussing community ownership of land in some African, Latin American and Asian countries, such as Mexico and Guatemala); see also Michael Trebilcock \& Paul-Erik Veel, Property Rights and Development: The Contingent Case for Formalization, 30 U. PA. J. INT'L L. 397, 416-17 (2008) (discussing empirical evidence for formalist and informalist perspectives).

50 See Keijiro Otsuka \& Frank Place, Land Tenure and Natural Resource MANAGEMENT: A COMPREHENSIVE STUDY OF AgRARIAN COMMUNITIES IN ASIA AND AFRICA 1-21 (2001) (discussing background research and the theoretical framework for the land tenure study); DEININGER, supra note 7, at 47; see generally DAVID A. Atwood, LAND REgistration IN AFricA: THE IMPACT ON Agricultural PRODUCTION, 18 WORLD DEV. 659, 659-71 (1990) (illustrating negative consequences of land titling and potential cheaper alternatives); JOHN W. BRUCE \& SHEM E. Migot-AdHolla, SEARCHING FOR LAND TenURE SECURITY IN AFrica (1994) (discussing the security of land tenure systems in Africa). 
titles and land governed by customary mechanisms alone. ${ }^{51}$ In Rwanda, the variable most strongly correlated with investment in land improvements was the right to bequeath land through customary mechanisms, rather than the right to sell land outside the clan group. 52

In urban informal settlements, there is proxy evidence that residents may also invest in housing, or transact rights to land, on the basis of perceptions of proprietary entitlements acknowledged by other members of their settlement. For example, in Vietnam less than $25 \%$ of all residential land had been registered by $2006 .{ }^{53}$ Yet, as at 2006, there was a booming market for urban residential land even in the absence of registered land titles. ${ }^{54}$ In East Timor, there is still no Land Law twelve years after independence, but there is a thriving urban market for house sales and condominium developments. ${ }^{55}$ In São Paulo, Brazil, 78\% of surveyed favela residents stated that they owned their dwellings, even though typically a fave-

\footnotetext{
51 See generally Timothy Besley, Property Rights and Investment Incentives: Theory and Evidence from Ghana, 103 J. POL. ECON. 903 (1995) (discussing the correlation of property rights and investment incentives in Ghana).

52 See Shem Migot-Adholla et al., Indigenous Land Rights Systems in SubSaharan Africa: A Constraint on Productivity?, 5 WORLD BANK ECON. REV. 155, 166-67 (1991) (discussing the benefit to land improvements of land that has been bequeathed); see also F. Place \& P. Hazell, Productivity Effects of Indigenous Land Tenure Systems in Sub Saharan Africa, 75 AM. J. AgRIC. ECON. 10, 14 (1993) (discussing a positive correlation between land rights and land improvements in Rwanda).

53 See Tran Nhu Trung, et. al., Shaping the Change: Vietnam Land Registration from Terminology to the Practice, XXIII FIG CONGRESS 12 (October 8-13, 2006), https://www.fig.net/resources/proceedings/fig_proceedings/fig2006/papers/t s39/ts39_03_trannhu_etal_0500.pdf (last visited July 8, 2016) [https://perma.cc/GLB8-TUEE] (discussing the progression of land registration in Vietnam).

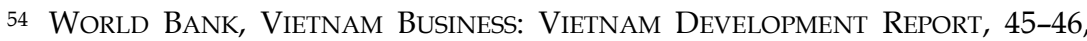
No. 34474-VN (Nov. 30, 2005), http://www-wds.worldbank.org/ external/default/WDSContentServer/WDSP/IB/2005/12/02/000160016_ 20051202141324/Rendered/PDF/344740VN.pdf (last visited July 8, 2016) [https://perma.cc/BXS8-ZN5D] (illustrating that the "real estate market emerged, and boomed, despite incomplete legal titling").

55 The President of East Timor (Timor-Leste) refused to promulgate a draft land law approved by the National Parliament in March 2012. See Warren Wright, President Horta Sends Land Law Back to Parliament, TimOR-LeSTE L. \& JusT. Bull. (Mar. 24, 2012), http://www.easttimorlawandjusticebulletin.com/2012/ 03/president-horta-sends-land-law-back-to.html?spref=bl [https://perma.cc/ 254X-AKUW]. The Council of Ministers approved a further draft land law on March 29, 2016. The National Parliament is slated to consider the draft law later in 2016. See MÉABH CRYAN, QUICK GUIDE TO THE CHANGES IN TIMOR-LeSTE'S EXPROPRIATION LAW (Tahan Briefing Note 1/2006, 2016) [copy on file with author].
} 
la develops on land legally held by another, including the state. Other studies of urban informal settlements identify factors such as duration of occupation, size of settlement, level of community organization, support from civil society or political representatives, and possession of local government documentation as determinants of perceptions of proprietary entitlements to land. ${ }^{56}$ These factors support the proposition that Demsetzian property claimants invest not only in land, but also in relations with local communities, civil society intermediaries and state representatives. The result can be a systemic form of property despite law - involving the coordination of proprietary rights at local scales of interaction but not at law.

\subsection{Formalizing Property: Mixed Results for Land Titling}

Even though local respect for Demsetzian property claims may create perceptions of property entitlements, notwithstanding the denial of de jure rights, there is evidence that legal formalization of informal property may further enhance incentives for investment or production. The implication is that, in some circumstances, informal property claims may develop de facto proprietary characteristics, but are still not generating optimal investment available under law. For example, there are studies that find investment and productivity improvements from systematic programs to provide documented freehold or long-term leasehold titles to land. The reported benefits include increases in farm-specific income (Brazil, China), 57 farm productivity and outputs (Peru, Philippines, Vietnam), ${ }^{5}$ housing investment (Guatemala), ${ }^{59}$ capital investment in

56 For a discussion, see REERINK, supra note 22, at 215, 221 (discussing factors that "contribute to housing consolidation.").

57 See Lee J. Alston, et. Al., The Determinants and Impact of Property Rights: LAND Titles on the BRAZilian Frontier, 12 J. L. ECON. OrG. 25, 57-58 (1996) (discussing the economic development of frontier settlements in Brazil); see generally ZHU KELIANG, ET. AL., THE RURAL LAND QUESTION IN CHINA: ANALYSIS AND ReCommendations BaSed on a SEVENTEEN-Province SurVeY, 38 N.Y.U. J. INT'L L. \& POL. 761 (2007) (discussing the economic development of China's rural tenure).

58 See Erica Field, Property Rights and Investment in Urban Slums, 3 J. EuR. ECON. Ass'́n. 279, 280-81 (2005) (discussing Peru); see also RAYMOND J. STRUYK \& ROBERT LYNN, DETERMINANTS OF HOUSING INVESTMENT IN SLUM AREAS: TONDO AND OTHER LOCATIONS IN METRO MANILA, 59 LAND ECON. 444, 453 (1983) (discussing Philippines); see generally QUY-TOAN. DO \& LAKSHMI IYER, LAND RIGHTS AND ECONOMIC DEVELOPMENT: EVIDENCE FROM VIETNAM (2002) (discussing Vietnam).

59 Thomas E. Schweigert, Land Title, Tenure Security, Investment, and Farm 
land (Thailand), ${ }^{60}$ and land values (Philippines, Peru, Ecuador and Venezuela). ${ }^{61}$ A meta-analysis that controlled for selection biases, such as the possibility that investment induces formalization, found from 20 empirical studies of systematic land titling programs an average increase of around $15 \%$ in consumption or income, and around $40 \%$ in the monetary value of land. There were no significant increases in access to credit.62 The studies included Latin America (Ecuador, Peru), Southeast Asia (Cambodia, Vietnam) and Africa (Ethiopia, Madagascar). 63

The meta-analysis of titling programs also found a puzzling disparity of results for Latin America and Southeast Asia as compared to sub-Saharan Africa. The authors hypothesize the possibility of an "Africa effect" - that the strength of de facto customary land systems in Africa reduced or eliminated the potential for de jure allocation of property rights to increase incentives for investment and production. ${ }^{64}$ For example, a comprehensive comparison in Madagascar of titled and untitled land found no significant difference in terms of recurrent investment, and only a small increase in land values that was not sufficient to justify costs of the titling program. ${ }^{65}$ The Madagascar findings are consistent with other studies that find more improvements in production and investment as a result of titling in urban and newly settled areas than rural areas with existing mechanisms for customary land management. ${ }^{66}$ These

Output: Evidence from Guatemala, 40 J. OF DEV. AREAs 115, 123 (2006) (studying the relationship between land title, investment and output).

60 Gershon Feder, et. al., The Determinants of Farm Investment and Residential Construction in Post-Reform China, 41 Econ. Dev. \& Cultural Change 1, 1-2 (1992) (discussing the incentives to having Chinese farmers make decisions).

61 See Gershon Feder \& Akihiko Nishio, The Benefits of Land Registration and Titling: Economic and Social Perspectives, 15 LAND Use POL'y 25 (1999) (Philippines); see generally Emmanuel Jimenez, Tenure Security and Urban Squatting, 66 THE REV. OF ECON. \& STAT. 556 (1984) (Peru, Ecuador and Venezuela). For an overview of empirical literature, see Trebilcock \& Veel, supra note 49, at 423-26.

62 See generally Ruth Hall, et. al., The Impact of Land Property Rights Interventions on Investment and Agricultural Productivity in Developing Countries: A Systematic Review, 10 CAMPBELl SYSTEMATIC REVIEWS (2012).

63 Id. at 35-38; see also Field, supra note 58, at 280 (discussing land titling in Peru associated with a $68 \%$ increase in the rate of housing renovation within four years of receiving a title).

64 Hall, et. al, supra note 62, at 2, 46-48.

65 See generally Hanan G. Jacoby and Bart Minten, Is Land Titling in SubSaharan Africa Cost-Effective? Evidence from Madagascar, 21 THE WORLD BANK ECON. REV. 461 (2007).

66 See, e.g., Jean O. Lanjouw \& Philip I. Levy, Untitled: A Study of Formal and 
studies suggest that the incentive effects of formalization are not only a product of de jure title, but also encompass the nature and presence of alternatives such as de facto mechanisms for acknowledging property entitlements.

\subsection{Hybrid Documents and Fragmented Land Markets}

The formalization of rights to land may not remove the potential for property system fragmentation. For example, even after systematic titling of ownership of land, there is evidence that large numbers of title-holders choose not to register subsequent transfers of rights in national systems of cadastral administration. The figures are striking. A study of the Philippines found that only $15 \%$ of titleholders register transfers of land with the central government. ${ }^{67}$ A study of urban land in Ghana found that $40 \%$ register land transfers with the national land agency. ${ }^{6}$ In Vietnam the figure for urban areas is $20 \% .69$ In the province of Aceh, Indonesia, only $14 \%$ of new female titleholders, and $24 \%$ of male titleholders, stated an intention to register subsequent transactions with the national land agency. ${ }^{70}$ In the Kenyan districts of Gathinga and East Kadianga, between $15 \%$ and $30 \%$ of all land sales in the period between 1966 and 1973 were registered in accordance with law. ${ }^{71}$ These low rates of subsequent or "derivative" registration land transfers are significant as they illustrate the potential for de facto coordination mechanisms to support markets in land irrespective of their status under law.

Informal Property Rights in Urban Ecuador, 112 THE ECON. J. 986 (2002) (hypothesizing that titling has most impact in areas without informal rules).

67 Floradema C. Eleazar, et al., Improving Land Sector Governance in THE PHILIPPINES: IMPLEMENTATION OF LAND GOVERNANCE ASSESSMENT FRAMEWORK (LGAF), (2013).

68 United Nations Human Settlements Programme, Ghana Housing Profile, (2011), at 80.

69 Mai Anh Nguyen, Analyzing the Encroachment Process of Informal Settlements in the Periurban of Ho Chi Minh City, Vietnam 36, 42 (2006) (examining the social networks of buyers).

70 WORLD BANK, STUdy ON GENDER IMPACTS OF LAND TITLING IN POST-TsunAMI ACEH, INDONESIA 102 (2011) (discussing gender components to access to justice and property rights in Aceh, Indonesia).

71 Simon F. R. Coldham, Land Tenure Reform in Kenya: The Limits of Law, 17 THE J. OF MOD. AFR. STUD. 615, 618 (1979) (discussing field-work suggesting the number of sales is not insignificant). 
A key variable for derivative registration of transactions is the presence of documentation that provides a substitute for law. The evidence suggests that large sections of land markets in the developing world rely on documentation other than the prescribed transactional forms of de jure land administration. Often, the documents are witnessed by local government officials, or issued by government agencies other than the land office. For example, in Laos, a land tax declaration is the standard form of documentation for transfers of rural land even though there are legal requirements to obtain a land survey certificate. ${ }^{72}$ In Langa, South Africa, informal land sale affidavits provide the documentary basis for most land sales notwithstanding legal requirements for specialist land notaries to prepare notarized sale contracts. ${ }^{73}$ In India, the documentary basis for land markets in informal settlements includes identity cards, tax receipts, electricity bills, ration cards or letters from state officials. In Indonesia, a 1990 survey of urban households found that only $5.3 \%$ of those without land title certificates (representing $63 \%$ of all respondents) had no form of government documentation at all, with most holding letters of sale witnessed by local officials, or letters of occupation issued by local officials. ${ }^{74}$ The extraordinary extent of semi-formal or non-prescribed land documentation in much of the developing world highlights the way in which Demsetzian claimants may invest in legitimizing their claims - generating expectations of coordinated respect for entitlements - through symbols of localized state actor recognition rather than the prescribed procedures of property law itself.

Many legal systems recognize land transfers that do not use standard form documentation where there is performance of a validly executed contract. In this event, law provides space for locally generated proprietary documentation, and the de jure rights-holder does not lose legal entitlements through failure to follow the law of

72 See generally BABETTE WEHRMANN ET AL., StUdY ON URBAN LAND MARKETS IN LAO PDR (2006); Babette Wehrmann \& Danilo R. Antonio, Intermediate Land Tenure: Inferior Instruments for Second-Class Citizens? 1 LAND TENURE JOURNAL (2010) (discussing issues surrounding intermediate tenure instruments).

73 Karol Bourdreaux \& Paul Dragos Aligica, Paths to Property: Approaches to INSTITUTIONAL CHANGE IN INTERNATIONAL DEVELOPMENT 60-63 (2007) (discussing "the South African government's programme to transfer legal title over residential property to residents of townships.").

74 See StRUYK, ET AL., supra note 23, at 93-95; see generally Jude WALlaCE, A. P. Parlindungan AND ARIE S. Hutagalung, INDONESIAN LAND LAW AND TENURES ISSUES IN LAND RIGHTS 2-9 (2000). 
land administration. However, a number of developing world jurisdictions have imported the Australian Torrens system, or its equivalents, and stipulate that title arises solely from registration in a national register regardless of the legal status of the contract of transfer. 75 In the absence of registration, transfers of title are enforceable inter partes but have no proprietary effect on third parties. The Torrens system establishes conditions for conflict between de facto and de jure property claimants where community practice is not to register transfers in the national titles register. ${ }^{76}$ For example, in Cambodia the 2001 Land Law provides that transfers of title have proprietary effect only as a consequence of registration of title. ${ }^{77}$ Yet there is evidence that less than $15 \%$ of titleholders transfer land according to legal requirements to register standardized transfer documents. ${ }^{78}$ The legal result is that a majority of purchasers or inheritors of land have no de jure rights even where the land was subject to titling because there was no registration of transfer at a point on the historical chain of title. Once there is a failure to register a transfer of ownership, all subsequent purported transfers lack proprietary effect at law, as transferees cannot receive a better title than the transferor. In these circumstances, the bright-line design of property law may exacerbate the potential for fragmentation of $d e$ facto and de jure claimants - as it categorizes large segments of a land market as illegal notwithstanding their persistence as social practice.

75 The list of jurisdictions includes Papua New Guinea, Malaysia, Vietnam, Cambodia, China and Vietnam. For examples, see Property Rights Law of the People's Republic of China, art. 9 (2007) FAGUI QUANSHU 2-12 (Property Rights Law) ("Unless otherwise provided by law, the establishment, modification, transfer and lapse of the right in real property shall only take effect upon registration pursuant to laws"); see also the Vietnam Land Law 2013, Law No. 45/2013/QH13, art. 183(3) (2013) (“The exchange, transfer, lease, sublease, inheritance, donation or mortgage of land use rights... must be registered... and will take effect from the time of registration").

76 See Daniel Fitzpatrick, Disputes and Pluralism in Modern Indonesian Land Law, 22 YALE J. INT'L L. 171, 186 (1997) (providing a discussion in relation to Indonesia).

77 Land Law of 2001, art. 65 (Cambodia) (discussing the enforceability of transfer of ownership).

78 Mark Grimsditch \& Nick HeNDERSON, UnTITLED: TenURE INSECURITY AND INEQUALITY IN THE CAMBODIAN LAND SECTOR 41-42, 106 (2009). 


\subsection{Property Despite Law}

To summarize: evidence from the developing world suggests large numbers of landholders denied recognition by law, or who choose not to resort to law, are Demsetzian claimants of property rather than mere claimants of personal licenses to occupy or use land, or self-acknowledged "squatters" lacking proprietary entitlements altogether. These claimants engage in long-term acts of use and exclusion. They transact land on the basis of assumptions of property entitlements. They seek documentary evidence of entitlements even when they act in contravention of law. They invest not only in production but also in mechanisms to legitimize their claims. Their property claims have proprietary characteristics in so far as family, neighbors and other community members coordinate behavior on the basis of expectations of respect for their claims. Moreover, their strategic responses to law help to define the property system outcome. In particular, they create conditions for fragmentation of de facto and de jure property sub-systems when they resist or ignore law in favor of coordination mechanisms that lack the benefit of recognition by law.

The evidence further suggests two basic types or circumstances of fragmentation. First, there are property claimants who are denied recognition by law but receive local recognition of property-like entitlements. Second, there are property claimants who receive legal recognition but decline to resort to law. Both types of cases involve decisions to ignore law in favor of extra-legal institutions. These decisions are optimal where a property claimant chooses not to resort or submit to law because alternative institutional arrangements - such as local norms or customs-lower the costs of property more effectively than law. ${ }^{79}$ The institutions of property are aligned as they allow resource users to "mix and match" strategies of recourse to law and alternative coordination mechanisms in order

79 ELLICKSON, supra note 1, at 167, 283 (discussing, for example, where the administrative costs of norm-based arrangements are cheaper than those associated with recourse to formal law). A property claimant may also make a rational decision not to enforce claims to an asset or attributes of an asset. She may relinquish control to another claimant because of the prohibitive costs of preventing infringement. See, e.g., YORAM BARZEL, ECONOMIC ANALYSIS OF PROPERTY RIGHTS 93 (2d ed. 1997) (providing examples -the owner of a restaurant may choose not to delineate or enforce property rights to salt in the restaurant. The owner of a grocery store may choose not to enforce rights to all attributes of cherries on display in the store.). 
to reduce the total costs of property. ${ }^{80}$ This article focuses on circumstances of misalignment-where the net costs associated with property-information, delineation and enforcement-are greater for the property system as a whole because of competition among de facto and de jure sub-systems of property. ${ }^{81}$

\subsection{The Politics of Fragmentation}

The following sections begin the enquiry into the causes of property system fragmentation with economic theories of the evolution of property. The starting point is public choice theory. Public choice provides an explanation for property systems that deny de jure rights to long-term occupiers or users of land. ${ }^{82}$ Legislators may "sell" property legislation not only for votes, but for campaign contributions, or even bribes. ${ }^{83}$ Political actors may receive private benefits from the power to allocate de jure property rights to members of a constituency or interest group without necessarily incurring the costs of compensating Demsetzian claimants who do not receive de jure property. ${ }^{84}$ Stuart Banner provides the example of

\section{Id. at 50.}

81 See Terry L. Anderson \& Peter J. Hill, Cowboys and Contracts, 31 THE J. OF LEGAL STUD. S489, S490 (2002) (discussing the potential for dissipation of rents in process of competing for property); see also Lee Anne Fennell, Ostrom's Law: Property Rights in the Commons, 5 INT'L J. OF THE COMMONS 9, 15 (2011) (discussing rational decisions not to submit or resort to law may even create negative spillover effects for the broader property system); see generally Lee Anne Fennell, The Problem of Resource Access, 126 HARV. L. REV. 1472 (2013) (classifying the various costs of property - information, exchange and enforcement - in terms of the costs of resource access). The potential for sub-optimal property outcomes includes the "tragedy of the anticommons", where too many property rights in a resource lead to deadlock and under-investment, for further discussion, see generally Michael A. Heller, The Tragedy of the Anticommons: Property in the Transition from Marx to Markets, 111 HARV. L. REV. Ass'N 621, 678 (1998). Unlike most studies of anticommons problems, which consider their effects on investment, this article provides explanations for their emergence in circumstances of competing de facto and de jure claims to land.

82 See, e.g., Barry C. Field, The Evolution of Property Rights, 42 KYKLOS 319, 33540 (1989) (discussing political institutions and the evolution of property).

83 Dennis C. Mueller, Public Choice II: A Revised Edition of Public Choice 344 (1989).

84 David D. Haddock, Force, Threat, Negotiation: The Private ENFORCEMENT OF Rights, reprinted in PROPERTY Rights: COOPERATION, CONFLICT, AND LAW 187 (Terry L. Anderson \& Fred S. McChesney eds., 2003) ("In the absence of effective limits, government actors are at least as apt to extract property 
de jure property allocation in British colonial systems. Minoritarian control over coercive political structures minimized the costs of de jure property allocation by avoiding distributional compensation to de facto claimants such as indigenous groups. 85

Public choice analysis leads to the proposition that political institutions are the primary determinants of a property regime that denies large numbers of Demsetzian claims to land. The proposition is related to a broader hypothesis formulated by Acemoglu, Johnson and Robinson - that political power is the primary determinant of all economic institutions. ${ }^{86}$ This hypothesis deserves some discussion as it illustrates limits on public choice explanations for the evolution of property system fragmentation. In relation to property, Acemoglu et al. adopt the public choice proposition that de jure political power-holders have incentives to develop property rules, and allocate property rights, in order to ensure the future flow of rents. De facto political power can override de jure political power, as in the case of rebellion or military coups. ${ }^{87}$ However, de facto political power is transient unless it translates into de jure power, as de facto power requires sustained episodes of collective action. Therefore, they argue, the key determinant of a property system is de jure political power. 88

Acemoglu et al. illustrate their model for the formation of economic institutions with the example of property under European colonization. Colonies with a European minority produced institutions that failed to define or enforce the property rights of the ma-

rights as to protect them.").

85 See Banner, supra note 4, at S369 ("A powerful oligarchy can thus overcome the problem of administrative costs simply by not being particularly rigorous in valuation and assignment of the property rights of the majority."); see also KATHRYN FIRMIN-SELlers, THE TRANSFORMATION OF PROPERTY RIGHTS IN THE GOLD COAST: An EMPIRICAl ANAlysis ApPlying Rational CHOICE THeORy 7 (1996) (describing property transitions in Ghana under British rule).

86 See Acemoglu et al., supra note 5 (expanding their analysis of the determinants of colonial institutions to a general theory of institutions and their causal relationship to long-run growth); see also Daron Acemoglu, Simon Johnson \& James A. Robinson, The Colonial Origins of Comparative Development: An Empirical Investigation, 91 AM. ECON. REV. 1369 (2001) (discussing the effect of institutions on countries' economic performance, as defined by income per capita).

87 Acemoglu et al., supra note 5, at 386-90.

88 Path dependence develops as de jure political power-holders strengthen their capacity to block attempts at institutional change through the accrual of wealth and increasing returns from investment in status quo institutions. $I d$. at 390-92. 
jority, including protection from state predation and expropriation of land. The European minority had de jure political power, but lacked economic incentives to secure the property rights of the majority due to the extractive nature of colonial activity. ${ }^{89}$ For example, the endowments of Latin America and the Caribbean favored distributions of political power based on large-scale plantations and exploitation of enslaved or indentured labor. There was a cheap supply of labor as a result of high population densities or access to the slave trade. Both the climate and the quality of soil suited crops such as sugar, coffee and tobacco with scale economies in plantation production..$^{90}$ Without de facto political responses (i.e. revolutions), the political elite had incentives to design institutions that facilitated state expropriation of land, and restricted opportunities for smallholder landownership, as a result of economic dependence on abundant cheap labor and ready access to land.

In the subject territories of European colonization, state-centric features of colonial land law-that the state had allodial title or sovereign control over land, and that proprietary interests in land derived from state grant or recognition-allowed colonial administrations to deny ownership rights to large numbers of possessory and customary claimants of land. 91 This much is consistent with a focus on de jure political power as the primary determinant of property. Yet, in many colonial cases, the formal allocations and demarcations of law did not align with historical or actual facts of control on the ground. ${ }^{92}$ While some colonial states, such as the socalled Neo-Europes of Australia, Canada and the United States, developed the capacity to enforce de jure rights to land, usually as a result of military conquest and forcible dispossession of indigenous groups, ${ }^{93}$ most lacked the financial, administrative, or military ca-

89 Acemoglu et. al., supra note 5, at 416; see also KenNETH L. SOKOLOFF \& STANLEY L. ENGERMAN, FACTOR ENDOWMENTS, INSTITUTIONS, AND DIFFERENTIAL PATHS OF GROWTH AMONG NeW WORLd ECONOMIES, reprinted in HOW LATIN AMERICA FELL BEHIND 260-304 (Stephen H. Haber ed., 1997).

90 Acemoglu et al., supra note 5, at 400; see also Alston et al, supra note 11, at 754-65 (providing further illustrations from their survey of settlement frontiers in Eastern Australia, the Great Plains of the United States, and Brazil).

91 See Patrick McAuslan, Bringing the LAW BACK IN: Essays IN LAND, LAW AND DEVELOPMENT 59-75 (2003) (describing how European land laws shaped land ownership in Commonwealth Africa).

$92 \mathrm{Id}$.

93 See Stuart Banner, Possessing the Pacific: LAND, SETtlers, AND INDIGENOUS PEOPLE FROM AUSTRALIA TO ALASKA, 2 (2007) (noting that, while neither Britain nor the United States had official policies of disregarding the property 
pacity to extend the enforcement authority of state agencies over all parts of their territory, particularly in the face of resistance by putative colonial subjects. 94

The implications of resistance to law are under-analyzed in public choice accounts of the evolution of property systems. Acemoglu et al. argue that the exercise of de facto political power through collective acts of rebellion affected the formation of economic institutions such as property through regime change, or changes in the policies of governing regimes. Yet, there were other acts of resistance that contributed to localized processes of property coordination without changes in formal policy, or configurations of de jure political power. As James Scott notes, there were comparatively few cases of colonial rebellion, and fewer again that induced regime change, relative to the long time frames, geographic reach, and exploitative nature of European colonization. ${ }^{95}$ Large numbers of colonial subjects engaged not in acts of rebellion but in "the weapons of the weak"- - acts of foot-dragging, evasion, studied ignorance, and false compliance that created everyday resistance to law. ${ }^{96}$ Many of these everyday acts of resistance did not involve collective political action. Yet they influenced property outcomes in a number of ways, not only by increasing the costs of legal enforcement, but by asserting alternatives to law - the potential for de facto property systems to persist notwithstanding law. ${ }^{97}$

Public choice analysis may not explain individual decisions to pursue de facto proprietary claims, but it does help to explain state

rights of indigenous people, the various mechanisms by which indigenous peoples lost their land were characterized more by compulsion that by consent).

94 See, e.g., Franz vON BENDA-BECKMANN, Property In SOCIAL Continuity, Continuity AND CHANGE IN THE MAINTENANCE OF PROPERTY RElationships IN MinangKabau, West Sumatra (1979) (Indonesia); SANDRA Fullerton JoIREMAN, PROPERTY Rights AND POlitical DEVElOPMENT IN ETHIOPIA AND ERITREA 66 (2000) (African states); Christian Lund, Local Politics AND THE DYNAMics OF PROPERTY IN AFRICA (2008) (Ghana); Sally Engle Merry, Law and Colonialism 25 LAW \& Soc'Y REV. 897, 918 (1991) (British colonies in Africa). For an overview, see generally Sally F. Moore, Changing African Land Tenure: Reflections on the Incapacities of the State, 10(2) EUR. J. DeV. Res. 33 (1998).

95 See generally JAMES SCOTT, WEAPONS OF THE WEAK: EVERYDAY FORMS OF PEASANT RESISTANCE, xv-xvi (1985).

96 Id. at xvi-xvi, 241-89 (discussing examples from a Malay village).

97 At times, the result was mutually constitutive interactions between law and the acts of property "outlaws." See, e.g., BANNER, supra note 93, at 5 ("the actions and characteristics of indigenous people ... generated local policies that were later incorporated into decisions made in London or Washington"). 
actor decisions not to enforce law-which is a feature of the cases of property system fragmentation discussed in Section I.A. Failures to enforce de jure rules or rights are central to property system fragmentation as de facto claims only persist in the absence of state coercion. There may be no enforcement of de jure rules or rights where state enforcement agents calculate that the costs of enforcement are not worth benefits such as satisfaction of job requirements or political commands, accrual of reputations for competence, or satisfaction of constituency demands for "law and order". However, even in these circumstances, decisions not to enforce law may also involve issues of resistance to law. Acts of violent resistance may increase the costs of coercion to the point where there are no net benefits to coercive state enforcement of de jure claims. ${ }^{98}$ For example, in relation to land, initial encroachment of de jure claims on low value land may not justify acts of resistance or defense by de facto claimants. Marginal increases in encroachment will increase the marginal value of land left under the control of de facto claimants. ${ }^{99}$ The capacity for state enforcement may then reach an equilibrium point where the marginal costs of state enforcement of de jure claims equals the marginal value of residual land left in the hands of de facto claimants.

To summarize: there is a body of public choice scholarship that analyzes the evolution of property systems in terms of de jure political power and its effects on the design of law.100 Politicallydesigned rules establish payoffs and strategic options - the incentive structures for economic interaction. ${ }^{101}$ Yet, limiting the evolution of property systems to the political design of law begs the question: can a focus on rules alone explain contemporary phenomena such as property system fragmentation? A conceptual frame for

\footnotetext{
98 For example, the police must take into account the potential costs of acts of violent resistance by property violators in exercising discretionary authority to engage in enforcement.

99 For a model of equilibrium enforcement results with reference to violence between the Paiute Indians and ranchers in the Owens Valley, see Haddock, supra note 84 , at $174-75$.

100 See, e.g., DOUglass NORTH, FIVE PROPOSITIONS ABOUT INSTITUTIONAL CHANGE, IN EXPLAINING SOCIAL INSTITUTIONS 18 (Jack Knight \& Itai Sened eds., 1995) ("It is not possible to develop a theory of institutional change that mixes up the players and the rules of the game. Institutions are the rules of the game and organizations are the players .... Modeling institutions is modeling the manmade constraints on human interaction.").

101 See SENED, supra note 4 , at 61.
} 
property system fragmentation must go beyond the political processes that produce a legal rule, or enforcement of the rule, to explain the way in which the rule fails to establish a shared basis for the coordination of property behavior. In other words, a focus on de jure political power as the primary determinant of property does not provide a conceptual frame either for decisions to resist or ignore law, or for de facto property systems that self-organize and persist notwithstanding law. While public choice narratives provide a framework to analyze interest groups or organizations, and the role of the state in the design of property rules, they do not provide a comprehensive theory of the comparative pathways of propertyhow some systems develop chronic contests, fragmentation and overlaps among de facto and de jure mechanisms for the governance of land.

\subsection{The Limits of Cost/Benefit Analysis}

What, then, of Demsetzian analysis? Does it explain the evolution of property system fragmentation? On its face, the cost/benefit framework set out by Harold Demsetz in 1967 did not allow for the possibility of contests among de facto and de jure property claims. ${ }^{102}$ The analysis predicts the emergence of clear property rights as rising resource values increase the net benefits of property, or technological change reduces the net costs of property. ${ }^{103}$ Individuals claim property over a resource or its attributes once the costs of exclusion are worth the benefits. The cost/benefit decision to claim property leaves a property entitlement in the hands of the party that values it the most. By definition, the outcome is "optimistic" as that party has optimal incentives not only to invest in production but also to reduce the social costs of resource competition by monitoring resource use and excluding outsiders (including competing property claimants). ${ }^{104}$

102 Demsetz, supra note 2.

103 Demsetz, supra note 2, at 350. See Terry L. Anderson \& P. J. Hill, The Evolution of Property Rights: A Study of the American West, 18 J. L. \& EcoN. 163, 164-68 (1975) (examining property rights definition and enforcement activities through the framework of a marginal decision model in order to deepen and substantiate the discussion of property rights decisions as reflections of marginal costs and benefits).

104 See Demsetz, supra note 2, at 347-48, 350 (elaborating on property as a 
Demsetz's analysis does not identify collective mechanisms for the evolution of property. The collective question arises from the problem of distributional losses - there must be a collective mechanism to ensure compliance with property as otherwise de facto claimants who lose from a de jure property entitlement lack incentives to respect that entitlement. ${ }^{105}$ Distributional losses are a product of the asymmetric value of property. Even if all parties are better off as a result of property, because of increases in the costs of resource competition, the party receiving the property right will benefit more than the parties that forego a right. Distributional losers may anticipate greater payoffs from non-cooperation or appropriation of a resource than compliance with claims of property rights to the resource. In these payoff circumstances, clear or uncontested property rights may not emerge because of the potential value of property for each party, the distributional losses of no property for the other party, and the strategic option of hold-outs or appropriation for each party. ${ }^{106}$ For example, land titling may vest lawful owners with rights of exclusion and alienation, thereby reducing the social costs of resource competition. Yet, it also creates distributional losers where it denies the claims of others to rights of use, access or future interests - giving rise to incentives for acts of resistance to law that may contribute to fragmented property system outcomes.

Absent collective mechanisms, there are circumstances where distributional losers may submit to law notwithstanding the loss or denial of property entitlements. That is, so-called squatters may ac-

mechanism to internalize externalities).

105 For discussion of analytical gaps in Demsetz's thesis, see James E. Krier, The Tragedy of the Commons, Part Two, 15 Harv. J. L. \& PuB. POL'Y 325, 338 (1992) (including logical circularity of predictions that a community can coordinate out of circumstances of non-coordination); Carol M. Rose, Property as Storytelling: Perspectives from Game Theory, Narrative Theory, Feminist Theory, 2 YALE J. L. \& HUMAN. 37, 51 (1990) (noting how Demsetz uses narrative or storytelling to glide over gaps in the analysis, particularly in relation to distributional effects of property transitions).

106 In order to reach agreement, therefore, the contract may require side payments to compensate distributional losses incurred by the party that does not receive the property right. Yet, in the absence of third-party enforcement, or cooperative incentives arising from repeat interactions among participants, a distributional loser may not agree to compensation because there is a problem of ex ante commitment: the property beneficiary cannot credibly commit to the promise of compensation without a mechanism to ensure compliance with the agreement. For a technical discussion, see AVINASH K. DIXIT, LAWLESSNESS AND ECONOMICS: AlternATIVE Modes OF GOVERNANCE 14-15 (2011). 
cept or submit to law where they acknowledge state authority to remove them from their land, or refrain from investing or transacting in land because of their status under law. The incentives to accept law notwithstanding distributional losses have Demsetzian elements - not only fear of punishment by the state, or the discounted benefit of state compensation, but also calculations of the costs of unresolved competition for resources, including the possibility of violent conflict over land. Conversely, individual incentives to resist law arise where the value of lost entitlements exceed the combined costs of resource competition, potential punishment or foregone compensation. Where Demsetzian claimants make cost/benefit decisions to resist law, the result is chronic fragmentation among de facto and de jure property systems if neither de jure claimants nor the state are willing or able to enforce law, and there is no resolution of conflict through agreement among de facto and de jure property claimants. In all these respects, individual responses to law are susceptible to Demsetzian analysis.

The limits of Demsetzian explanations for property system fragmentation remain the issue of collective mechanisms to ensure respect for property. ${ }^{107}$ A critical mass of property users, transactors and potential violators may choose to resist law not only because of Demsetzian calculations of net distributional losses from law, but because of a collective lack of familiarity with law, or an absence of belief in the legitimacy of state legal order. Property claimants may act collectively to resist law simply because it is the product of a distant centralist state, or a state they perceive as lacking in reliability, legitimacy or probity. Others may ignore law, even in circumstances where there is the possibility of recognition by law, because they prefer group-based property institutions embedded in long-standing mechanisms of social organization. Their expectations of behavior may be shaped by self-identification as members of a community, tribe, or network rather than citizens of a constitutional state. In all these senses, there is a need to explain the phenomenon of property system fragmentation through analysis of collective processes as well as the cost/benefit calculations of preference-maximizing individuals.

\footnotetext{
107 See infra Section 3.2. ; see generally EdUARDO MOISÉS PEÑALVER \& SONIA K. Katyal, Property Outlaws: How Souatters, Pirates, and Protesters Improve THE LAW OF OWNERSHIP (2010) (identifying ways in which resistance to law may affect the evolution of property system fragmentation - not only in terms of formal rules but also for the everyday practices of property).
} 


\section{A CONCEPTUAL FRAME FOR PROPERTY SYSTEM FRAGMENTATION}

This part develops a conceptual frame for property system fragmentation that focuses on coordination. Coordinated property relations may emerge without the need for law. The standard example is respect for possession-where possession provides the basis for expectations of compliance with property. Another example is custom-where expectations of respect for custom provide the basis for compliance with property. A coordination lens is useful as fragmented property outcomes may emerge when law overlays property systems based on possession or custom. In particular, there is a misalignment of coordination mechanisms that creates fragmented outcomes when law attempts, but fails, to replace private systems of property coordination. These circumstances create scope for individuals to resist or ignore law in favor of coordination mechanisms that lack the benefit of recognition by law. Coordination analysis thus highlights the significance of transitions to law, as part of processes of state formation, for the evolution of fragmented property systems.

The analysis highlights the need for analytical approaches to property system fragmentation that encompass not only individual cost/benefit calculations but also collective processes of social organization. Focal points for property coordination are not solely or simply asymmetrical features of the environment, selected by rational actors to avoid costly conflict over resources. They require reproduction through social techniques of legitimation, such as ritual, symbols, and mythology, in order to ensure continued selection as a basis for coordination. ${ }^{108}$ They operate at different scales of interaction - across axes or dimensions of space, time and public authority. Their scale-sensitive interactions increase as property systems develop complexity, particularly as systems of law, and the state, superimpose arrangements based on families, neighborhoods, communities, or networks. In all these senses, focal points such as possession, custom or law have structural or systemic qualities that require macro-analytical frames beyond individual choice-making by rational actors.

108 See generally CAROL M. Rose, Property AND PERSuasion: Essays ON THE HISTORY, THEORY, AND RHETORIC OF OWNERSHIP 9-24 (1994) (stating that persuasion is integral not only to initial claims of property but to property institutions generally). 
Coordination in complex property systems may give rise to subsystems, where groups self-organize at different scales of interaction. Each property sub-system may develop distinct structures, imperatives and processes for self-organization. ${ }^{109}$ Fragmented outcomes emerge from property sub-systems where there is systemic resistance to law, either because there are weak structural linkages with law or the state, or because the sub-system has self-organizing imperatives that are misaligned with state legal order. For example, individuals may choose not to submit or resort to law where legal transition undermines the self-organized basis of their property subsystem. They interpret law as being costly even though, on its face, the law provides optimal reductions in the costs of property. Alternatively, they may choose not to submit or resort to law because their property sub-system lacks structural links with law or the state. Law may have salience and familiarity for actors affiliated with the state, but not for members of property sub-systems that pre-date the state. ${ }^{110}$ In the language of systems theory, all these possibilities highlight the issue of emergence - the way in which micro-behavior interacts with macro-patterns of systemic ordering. 111

\subsection{Coordinating Property}

Property coordination is a behavioral phenomenon that gives rise to autonomous respect for property - as a supplement or replacement for first-party, second-party, or third-party mechanisms of enforcement. ${ }^{112}$ Thomas Merrill and Henry Smith illustrate

\footnotetext{
109 For an overview of systems theory in a context of law, see NIKLAS LUHMANN, LAW AS A SOCIAL SYSTEM (Klaus A. Ziegert trans., 2004).

110 John Gillespie provides a series of examples from East Asia and Vietnam. See generally John Gillespie, Towards a Discursive Analysis of Legal Transfers into Developing East Asia, 40 N.Y.U. J. INT'L L. \& POL. 657 (2008) (describing legal transfers into developing states in East Asia); John Gillespie, Exploring the Limits of the Judicialization of Urban Land Disputes in Vietnam, 45 LAW \& SOC'Y REV. 241 (2011) [hereinafter Gillespie, Judicialization] (providing a series of examples of the salience of law for actors that pre-date the state in East Asia and Vietnam).

111 For the standard account of emergence from a systems theory perspective, see JOHN H. Holland, EMERGENCE: FrOM CHAOS TO ORder (1998).

112 See ElLICKSON, ORDER WithOUT LAW, supra note 1, at 127 (setting out a tripartite classification of social control mechanisms as first, second, or third party in nature).
} 
property coordination in large group settings with reference to cars in a city. ${ }^{113}$ In any given city, there are large numbers of cars with owners or drivers that are not known to other owners or drivers, or to pedestrians or potential thieves. Of themselves, self-help measures to protect car ownership, such as alarms or steering locks, do not establish generally recognized expectations not to interfere with another person's car. Equally, legal actions to enforce ownership - through prosecutions for theft or civil actions in trespassmay shape expectations but are relatively infrequent compared to the total number of cars. Merrill and Smith conclude that coordinated behavior is necessary to underpin a property system as neither law nor self-help can solve the problem of ensuring compliance with property among a large group of unconnected people. ${ }^{114}$

Legal enforcement alone does not solve the problem of property compliance because of the high costs of coercion. ${ }^{115}$ In principle, there are no fragmented property outcomes where de facto claimants submit to law because they expect the state to use its comparative advantage in violence to punish infringement, and the net benefits of infringement are less than the anticipated costs of punishment. ${ }^{116}$ However, no state has the capacity to punish all those who infringe on property rights. Just as a private owner is unlikely to delineate and enforce all aspects of a property claim, so too is a state unlikely to rely on coercion alone even where it has a comparative advantage in the use of violence. ${ }^{117}$ For its part, selfhelp is also a limited mechanism for ensuring compliance with

113 See Thomas W. Merrill \& Henry E. Smith, The Morality of Property, 48 WM. \& MARY L. REV. 1849, 1854 - 55 (2007) (challenging the conventional wisdom that the systems of property and morality are disparate and cannot be reconciled).

114 Id. at $1854-55$.

$115 \mathrm{Id}$. at $1853-54$. For studies of property coordination in small group contexts, see Robert C. Ellickson, Property in Land, 102 YALE L.J. 1315, 1332 (1993) (discussing the advantages of group ownership of land) [hereinafter Ellickson, Property].

116 See Haddock, supra note 84, at 186 ("If a potential encroacher recognizes the superior might of the servants of the state, no violation will occur, and police and military violence will remain a potential rather than an actuality"). There is also an absence of fragmentation where law does not prohibit resort to private enforcement mechanisms: for an example from Japan, see J. Mark Ramseyer \& Mikael Adolphson, The Competitive Enforcement of Property Rights in Medieval Japan: The Role of Temples and Monasteries, 71 J. ECON. BEHAVIOR \& ORG. 660 (2009).

117 See Haddock, supra note 84, at 188 ("No government attempts to define rights comprehensively."). See also YORAM BARZEL, supra note 79 (discussing circumstances where private owners do not seek to enforce their entitlements). 
property as multiple resource users may calculate that the benefits of increased exclusion outweigh the opportunity costs of diverting resources from productive use. In the absence of third-party enforcement, each claimant may devote increasing resources to attack and defense in order to meet escalating threats of infringement, creating the potential for cycles of Hobbesian conflict over rights to resources. ${ }^{118}$

In game-theoretic terms, coordinated expectations of compliance with a property claim require payoff conditions where the value of a resource is less than the costs of fighting for control of the resource. ${ }^{119}$ These payoff conditions provide incentives for participants in a game of resource competition to select an asymmetrical feature of the environment - a focal point — in order to avoid costly acts of non-coordination. ${ }^{120}$ For example, where two cars approach an intersection at the same speed, with the same preference to be first, the intervention of a bystander who waves one car through provides a focal point that allows the parties to coordinate priorities so as to avoid a collision. Alternatively, a set of signs at the intersection may indicate which driver has the right of way. In these examples, the focal point provides a salient and unambiguous feature of the environment that both parties are likely to choose as a basis for coordinated behavior to avoid the worst possible outcome of mutual insistence on a right of way. ${ }^{121}$ A similar calculus applies to property. Focal points may provide a basis for coordinated expectations of respect for property in order to avoid the costly outcome of Hobbesian conflict over resources. ${ }^{122}$

118 For a discussion, see Fitzpatrick, supra note 7, at $128-29$. Because of the limits of private enforcement, this article focuses on coordination rather than firstparty enforcement strategies relating to property. (1980).

119 The seminal study is ThOmas Schelling, The Strategy of Conflict

120 For a discussion, see Krier, supra note 1, at 152. For a general introduction to focal point coordination, see ROBERT SUGDEN, THE ECONOMICS OF RIGHTS, COOPERATION AND WELFARE 65-86 (1986) [hereinafter Sugden, THE ECONOMICs of RIGHTS].

121 See generally Randal C. Picker, Simple Games in a Complex World: A Generative Approach to the Adoption of Norms, 64 U. CHI. L. REV. 1225 (1997) (explaining that where the payoffs are equal the choice of focal point is not affected by the distributional consequences of the choice. For example, motor vehicle drivers may choose either to drive on the left or right of the road - the choice has no distributional implications for individual drivers).

122 See JAMEs M. Buchanan, The Limits of Liberty: BetWEen ANARCHY AND LEVIATHAN 9 (1975) ("Escape from the world of perpetual Hobbesian conflict re- 
The following discussion considers three potential focal bases for property coordination-possession, custom, and law. The argument is that these potential focal points may align, overlap or compete at multiple scales of interaction - in ways that substantially determine the potential for property system fragmentation. The approach is stylized, case-based and inductive. ${ }^{123}$ Examples from East Timor, Kenya, and Cambodia generate the broad premise that property system fragmentation emerges when law attempts, but fails, to replace private systems of property coordination. East Timor illustrates the potential for fragmentation when simple legal rules of possession overlay complex possessory customs. Kenya illustrates the social embeddedness of custom as a source of resistance to law. Cambodia illustrates state formation and behavior as key variables in contested or partial transitions to law. Taken together, the case studies help to explain a key puzzle of property system fragmentation - why a critical mass of individuals may choose not to submit or resort to law even where law appears to provide cost-minimizing alternatives to other coordination arrangements.

\subsection{Possession and Law}

Possession may be a focal point in a game of resource competition as it provides a clear and visible sign of a relationship with a resource. ${ }^{124}$ The oft-cited example is that of the first car to enter a one-way bridge: it has the right of way as any other rule would be highly productive of social disorder. ${ }^{125}$ The focal point of possession selects the basis for coordination: when possessor, play hawk; when not a possessor, play dove. Ensuing patterns of coordination

quires an explicit definition of the rights of persons to do things").

123 For further discussion of case-based approaches to the formation of institutions generally, see ROBERT H. BATES et aL., ANALYTIC NARRATIVES (1998). For an example, see AVNER GREIF, INSTITUTIONS AND THE PATH TO THE MODERN ECONOMY: LESSONS FROM MEDIEVAL TRADE (2006).

124 See Krier, supra note 1, at 155 ("Possession is... usually unambiguous, and thus provides a clear indication of the status of any claimant").

125 See Andrea McDowell, Real Property, Spontaneous Order, and Norms in the Gold Mines, 29 LAW \& SOC. INQUIRY 771, 774 (2004) [hereinafter McDowell, Spontaneous Order]; see also Robert Sugden, Spontaneous Order, 3 J. ECON. PERSPECTIVE 85, 88 - 90 (1989) (providing more explanation of the example used); see also SUGDEN, THE ECONOMICS OF RIGHTS, supra note 120, at 70 - 71 . 
have self-enforcing characteristics where the best response of each participant is to defer to - or insist upon-possession given the expectation that other participants will adopt the same hawk/dove strategy. As a result, possession may provide a basis for property coordination in the absence of law, or even in the face of antagonistic law.

The mining rules of the Californian goldfields between 1848 and 1849 provide a standard illustration of first possession as a focal point for property coordination in the absence of law or thirdparty enforcement. ${ }^{126}$ The $19^{\text {th }}$-century Californian gold rush involved large numbers of miners entering an area that had recently been annexed by the United States from Mexico. ${ }^{127}$ Mexican law did not apply as of February 12, 1848, and there was no US federal mining law until 1852.128 There were no courts, police or jails, and only a small military force. ${ }^{129}$ Throughout 1849 , American miners developed mining codes that established a relatively low level of disputation despite the competitive nature of the rush for gold itself. ${ }^{130}$ Almost all the mining codes included rules of first possession that granted rights to the first person to dig a hole and stake a claim. ${ }^{131}$ While initial agreement among miners created the first possession rule, the rule generated widespread compliance in the absence of third-party enforcement because it served as a focal point mechanism to avoid costly conflict over resources. ${ }^{132}$

126 See Karen Clay \& Gavin Wright, Order Without Law? Property Rights During the California Gold Rush, 42 EXPLORATIONS IN ECON. HisT. 155, 177 (2005) ("The mining districts of the California gold rush [are] remarkable examples of orderly institution-formation in the absence of formal legal authority"); McDowell, Spontaneous Order, supra note 125, at 774.

127 See Clay \& Wright, supra note 126, at 158 - 69 (stating that in June 1848 there were around 5000 people working in the gold mines. By December 1849 there were approximately 40,000, and, by 1852, 100,000 gold miners in California).

128 See id. at $159-160$ ("No federal mining law was in existence at the time gold was discovered").

129 See McDowell, Spontaneous Order, supra note 125, at 771 (“[W]hen gold was discovered on January 24, 1848, the territory had none of the usual legal institutions such as a legislature, courts, police, or jails").

130 See id. at 771 ("When diggings looked promising... those who were on the spot held a meeting to pass a more detailed mining code for that particular area . . .$"$.

131 See Richard O. Zerbe and C. Leigh Anderson, Culture and Fairness in the Development of Institutions in the California Gold Fields, 61 J. ECON. HIST. 114, 133 - 35 (2001) ("First-come, first-served procedures were used by the California miners in establishing the choice of claims").

132 See id. at 133 ("[f]irst-come, first-served procedures can serve as focal 
The Californian gold-mining case is significant because it illustrates mass transitions to law as a result of increased costs of property in self-organized systems based on possession. From 1851 onwards, members of the Californian gold-mining associations resorted to the Courts, and then the procedures established by the US Mining Act 1871, to resolve increasing numbers of conflicts as the number and heterogeneity of miners increased, and technological changes allowed more capital-intensive mining utilizing wage labor. ${ }^{133}$ The transition was consistent with Demsetzian analysis as resource users moved from costly institutional arrangements. The potential for recourse to law provided the option of exit from selfgoverning property systems. ${ }^{134}$ The state had a relative advantage in reducing the costs of enforcing property based on its capacity to cross-subsidize the use of force. The costs of exit fell as more and more group members chose law. As group members migrated to law there was greater access to information on law and its potential benefits for other group members. ${ }^{135}$ Case-studies of this type of cost-minimizing transitions to law not only include Californian gold-mining associations but also the Amazon frontier in Brazil, where settlers sought title documents from the Brazilian state as their self-organized mechanisms of property allocation degraded under pressure from increased numbers and heterogeneity of settlers. ${ }^{136}$

Most economic studies of small self-organized property systems focus on simple acts of possession as the focal basis for property

points to avoid conflict because they appear to be fair"); see also McDowell, Spontaneous Order, supra note 125, at 176.

133 For an overview of the emerging disputes that led to legal transition, see Zerbe \& Anderson, supra note 131, at 114-143 (2001).

134 See Andrew P. Morriss, Hayek E Cowboys: Customary Law in the American West, 1 N.Y.U. J.L. \& LIBERTY 35, 35 - 37 (2005) (giving an example of self-governing legal systems in the American West).

135 A number of studies model the process of transition from relation-based to law-based systems of property. See, e.g., Avinash Dixit, Two-Tier Market Institutions, 5 CHI. J. INT'L LAW 139 (2004); see also Randall L. Calvert, Rational Actors, Equilibrium and Social Institutions, in EXPLAINING SOC. INSTITUTIONS, 57 (J. Knight \& I. Sened eds., 1995). As Ellickson notes, there are countervailing competitive pressures for property sub-systems to minimize exit by their members; Ellickson, Property, supra note 115, at 1332.

136 See generally Lee J. Alston et al.,, A Model of Rural Conflict: Violence and Land Reform Policy in Brazil, 4 ENV'T \& DEV. ECON. 135 - 160 (1999) (providing more detail of the Brazilian case-study). 
coordination. The possession in question involves Lockean actsinputs of labor that create visible markers to outsiders. Hence, the California case involved relatively simple acts such as hole-digging and leaving tools in the hole. In a related study, the act of clearing a space for parking during Chicago snow storms, combined with markers such as leaving a chair in the cleared area, led to coordinated respect for entitlements without resort or reference to law (albeit with the potential for violent self-help acts). ${ }^{137}$ Both these studies are characterized by easy-to-understand acts of possession, and relatively brief periods of proprietary entitlement. In contrast, the following case study of East Timor illustrates complex possessory acts in multi-generational systems of property coordination. The case is useful as this type of multi-generational coordination mechanism is more typical of complex property systems relating to land than the short-lived cases of Californian gold-mining or Chicago car parking. The East Timor case illustrates the potential for fragmented outcomes when a state overlays legal rules of possession on possessory norms embedded in pre-state systems of social organization.

\subsubsection{Complex Possession in East Timor}

Each of the 26 or so ethno-linguistic groups in the new nationstate of East Timor have mythologies of ancestral first possession, where social precedence and identity derives from narratives of descent traced to a founding ancestor. ${ }^{138}$ Typically, the story of ancestral first possession involves migration to new land by the founding ancestor, combined with ritualized acts of appeasing the spirits of the land. Daniel Fitzpatrick and Susana Barnes argue that, in customary areas, mythologies of ancestral first possession act as a focal basis for property coordination because they provide a shared cultural basis for determining entitlements to land. ${ }^{139}$ In-migrants are aware they can obtain access to land, and avoid costly forms of conflict, through marriage into the group or allocation of land by the

\footnotetext{
137 Epstein, supra note 1, at S516, S519.

138 Daniel Fitzpatrick \& Susana Barnes, The Relative Resilience of Property: First Possession and Order Without Law in East Timor, 44 LAW \& SOC'Y REV. 205, 206 (2010) [hereinafter Fitzpatrick \& Barnes, Relative Resilience].

139 Id. at $216-26$.
} 
senior lineage of the group (i.e. the lineage most proximate by descent to the source of origin). ${ }^{140}$ Most in-migrants that engage in Lockean acts of clearing, cultivation and house construction continue to define their proprietary entitlements by reference to relationships with lineages tracing descent to the ancestral first possessor(s). ${ }^{141}$ Over a very long period of time, the nesting of Lockean concepts of possession within a broader principle of ancestral first possession has acted as a cultural technique for maintaining property coordination in circumstances of human mobility and exogenous marriage. ${ }^{142}$

Within customary groups, there are tensions between entitlements based on claims of direct descent from founding ancestors and claims based on Lockean acts of possession. For example, some subordinate households or lineages place boundary markers on land left fallow, even though the senior lineage has broad authority over fallow lands. ${ }^{143}$ In addition, in coastal areas first cleared under colonial Portuguese supervision, there are household claims to land based not on customary allocation pursuant to ancestral origin narratives, but on unqualified assertions of Lockean posses-

140 In the patrilineal societies of the island of Timor, the senior lineage descends through the eldest son of the founding ancestor (and through the eldest daughter for the matrilineal Ema group). For an overview, see Fox, J, 'Installing the 'outsider' inside: the exploration of an epistemic Austronesian cultural theme and its social significance', Indonesia and the Malay World, Vol. 36, No. 105, pp. 201 - 218 (2008).

141 See Renee B. Clamagirand, The Social Organization of the Ema of Timor, in THE FLOW OF LIFE: ESSAYS ON EASTERN INDONESIA 231 (James. J. Fox ed., 1980) (discussing "wife-giver/wife-taker" relations among the Ema ethno-linguistic group of East Timor); see also James J. Fox, Austronesian Societies and Their Transformations, in The Austronesians: Historical And Comparative Perspectives 229 (Peter Bellwood et al., eds., 2006) (discussing "wife-giver/wife-taker" categories in the light of cultural metaphors of precedence among Austronesian groups in the eastern Indonesian archipelago); see also ElizABETH B. TRAUBE, COSMOLOGY AND SOCIAL LIFE: Ritual EXCHANGE AMONG THE MAMbAi OF EAST Timor (1986) (discussing "male" and "female" houses of origin among the Mambai ethno-linguistic group of East Timor).

142 See Fitzpatrick \& Barnes, Relative Resilience, supra note 138, at 218 - 26 (discussing in-migration and cultural incorporation techniques in the village of Babulo, Lautem District); see also Andrew R. McWilliam Customary claims and the public interest: on Fataluku resource entitlements in Lautem, in EAST TIMOR: BEYOND INDEPENDENCE 165 (D. Kingsbury \& M. Leach eds., 2007) (exploring in-migrations and customary notions of precedence on the Eastern district of Lautem).

143 See generally Daniel Fitzpatrick \& Andrew McWilliam, Bright-Line Fever: Simple Legal Rules and Complex Property Customs among the Fataluku of East Timor, 47 LAW \& SOC. REV. 311 (2013) [hereinafter Fitzpatrick \& McWilliam, Bright-Line Fever] (exemplifying the complexity of bright-line property rules in East Timor). 
sion - such as clearing and digging irrigation channels - combined with the grant of a hoe by village government officials appointed by the Portuguese colonial administration. ${ }^{144}$ In each case, claims of possessory entitlements require iterated acts of legitimationinvolving mythology, ritual, and symbols — as simple physical acts of possession alone are not sufficient to generate expectations of respect for entitlements. Often, these acts of legitimation also involve reference to systems of authority-for example, the original authority of senior customary lineages or the political authority of colonial administration. ${ }^{145}$ The implication is that possessory entitlements embed over time in systems of authority, identity, and social organization-as a long-term consequence of human mobility, exogamous marriage, and regime change.

East Timor (Timor Leste) attained independence in March 2002. A land law approved by the Parliament of the new nationstate now purports to recognize individual acts of long-term possession as a basis for alienable ownership rights to land. ${ }^{146}$ The entitlement extends to land claimed by customary groups. ${ }^{147}$ Possessors are defined to include those who reside in, have erected buildings on, or have cultivated land - even where that land is claimed by another party on the basis of ancestral customary domain. The law thus adopts legal principles of possession based on physical use of land rather than social understandings of the proprietary significance of possessory acts. The result is different epistemic conceptualizations of property and possession, which creates barriers to the

144 Janet Gunter, Communal Conflict in Viqueque and the 'Charged' History of '59, 8 Asia PAC. J. ANThropology 27, 34 - 35 (2007) (describing how the opening of large rice paddies created disagreements over land tenure).

145 See Fitzpatrick \& McWilliam, Bright-Line Fever, supra note 143 (providing a detailed discussion).

146 The law is not in force as the President of East Timor sent it back to the National Parliament for re-consideration in March 2012: see Wright, supra note 55. The draft law provides that a claimant may be entitled to ownership on the basis of continuous, peaceful and notorious possession that commenced on or before December 31, 1998, provided there is no predecessor title issued under Portuguese or Indonesian regimes to East Timorese citizens (art. 22).

147 Article 10(3) defines possessors to include those who reside in, have erected buildings on, or have cultivated land claimed by another party based on the belief of ancestral customary domain, even when rent is being paid to that party. This definition potentially allows persons that are not members of customary groups to claim alienable ownership of ancestral customary land. This category includes large numbers of people forcibly relocated during Indonesian times to land claimed by a customary group. For further discussion, see Fitzpatrick \& McWilliam, Bright-Line Fever, supra note 143. 
adoption of law as a new focal basis for property coordination. ${ }^{148}$ Understanding the coordination of property systems, on the basis of focal points such as possession, therefore implicates epistemic conceptualizations of property as well as historical mechanisms of social organization.

To summarize: expectations of respect for possession may provide the basis for coordinated property systems. While economic case-studies focus on small group settings, shared expectations of respect for possession may provide a basis for coordinated behavior in multi-scale property systems. The possibility of respect for possession helps to explain the emergence of property sub-systems in settings such as informal urban settlements. Residents who set out markers of occupation and labor may generate expectations of respect for their claims irrespective of law. At the same time, cases such as East Timor illustrate the embedded nature of possessory norms in complex settings involving long-term claims to land. Over time, proprietary claims based on possession embed in collective methods of social organization, and include investments in techniques of social legitimation. The implication is that analyzing fragmented property outcomes where law overlays systems based on possession requires attention not only to individual choices among institutional arrangements but to historicized methods of social organization, cultural techniques for social legitimation, and epistemic understandings of property and possession.

\subsection{Custom and Law}

Economic analyses identify a need for focal points other than possession at scales of resource governance beyond single-use production environments. To take a number of examples from the literature: where resources are newly available to claim, a simple convention of respect for possession may encourage costly races for possession as resource users escalate efforts to obtain possession in order to appropriate control of resources before other users. ${ }^{149}$ Rac-

148 See, e.g., Gillespie, Judicialization, supra note 110 (stating that the coordinated resolution of land disputes between the state and self-organized groups of its citizens may require a language or communicative medium that is mutually intelligible for all parties).

149 See Dean Lueck, The Rule of First Possession and the Design of the Law, 38. J. L. \& ECON. 393, 406-07 (1995) (explaining a contractual model). 
ing for possession may dissipate resources in conflict with other competitors, or through investments in unsuccessful acts of racing. Similarly, in common pool circumstances, rising resource values may cause a 'tragedy of the commons' to develop as a result of escalating exploitation of the flow from a resource when each possessor appropriates more, in anticipation of increased appropriations by other possessors. 150

In mixed-use circumstances, rising resource values increase incentives for individual possessors to shift the costs of their own use to other users, or to appropriate the benefits of other acts of resource use without bearing the costs of resource investments. ${ }^{151}$

Custom may act as a focal alternative or supplement to possession. Cases of custom as a focal point for property coordination include customary rules that mitigate the risk of competitive races for a resource or its flow. ${ }^{152}$ Typically, the information costs of custom are such as to require recursive techniques of ritual, symbolism and narrative in order to promote salience and shared understandings of custom as a focal point for property coordination. As Bourdieu notes, these recursive processes involve the habituation of individual choice - the internalization of social structure through acculturation techniques. ${ }^{153}$ The following case study of Kenya highlights customary principles of descent-reckoning as a powerful source not only of social structure but of expectations relating to land. For poststructuralist anthropologists, descent-reckoning is an outdated means of analyzing social organization, because of the manipulation of genealogies and settlement narratives by powerful actors. ${ }^{154}$

150 See Thráinn Eggertsson, Open Access Versus Common Property, in PROPERTY Rights: CoOperation, CONFlict, AND LAW 77-9 (Terry L. Anderson \& Fred S. McChesney eds., 2003).

151 See Henry E. Smith, Semicommon Property Rights and Scattering in the Open Fields, 29 J. LEGAL STUD. 131, 132 (2000) (discussing the use of the open-field system).

152 See generally ELINOR OSTROM, GOVERNING THE COMMONS: THE EVOLUTION OF Institutions for Collective Action (James E. Alt \& Douglass C. North eds., 1990) (providing an overview with examples).

153 See, e.g., Pierre Bourdieu, Distinction: A Social CritiQue of the JUDGEMENT OF TASTE 170, 471 (Richard Nice trans., 1984) (describing unconscious processes and cultural products of habituation that internalize notions of social order for individuals).

154 See Merry, supra note 94, at 904 (discussing lineage analysis in colonial contexts). Structuralism here primarily refers to structuralist schools of anthropology. While structuralism is most closely associated with the 1960's work of Claude Lévi-Strauss, structural anthropology has a longer pedigree in so far as 
Nevertheless, the Kenyan case suggests that descent-reckoning may provide a focal basis for property coordination notwithstanding the purported replacement of custom by law. The implication is that the embeddedness of coordination decisions in customary mechanisms of social ordering may explain decisions not to resort to law, even where the law appears to provide optimal reductions in the costs of property.

\subsubsection{The Embeddedness of Custom in Kenya}

Kenya provides an example where property law attempts to replace custom with bright-line rules of title registration and transfer. In particular, the Registered Land Act 1962 and the Land Adjudication Act 1968 establish mechanisms for the conversion of customary rights to land into registrable statutory interests. The registered proprietor of land obtains "absolute ownership... free from all other interests and claims whatsoever," subject to interests recorded on the titles register and overriding interests set out in the Land Act. This principle of indefeasibility of registered title is basic to Torrens systems of land law. Customary law no longer applies to the legal conveyance of proprietary interests in land as legal title arises from the registration of prescribed written instruments rather than performance of the contract of transfer. ${ }^{155}$ The Torrens principle that

earlier anthropologists sought to identify systemic patterns from fine-grained studies of social behavior. For more examples of this, see A. R. RADCLIFFEBROWN, STRUCTURE AND FunCTION IN PRIMITIVE SOCIETY (1952) and Claude LéviStrauss, Language and the Analysis of Social Laws, 53 AM. ANTHROPOLOGIST 155 (1951) (describing a relationship between linguistic analysis and the comparative study of customs, institutions and behavior). Post-structuralism seeks to move beyond assumptions of shared meaning to consider processes of imposition or negotiation of meaning. This is illustrated by JACQUES DERRIDA, WRITING AND DIFFERENCE (Alan Bass trans., 1967) (providing canonical statements of poststructuralism) as well as ROLAND BARTHES, ElEMENTS OF SEMIOLOGY (Annette Lavers \& Colin Smith trans., 1967). A key feature of poststructuralist approaches is the deconstruction of meaning - the de-centering and re-ordering of assumptions to explore the processes and power relations behind productions of meaning. For a broad discussion of structuralist theory, see Jack M. Balkin, Deconstructive Practice and Legal Theory, 96 YALE L.J. 743 (1987) (applying Derrida's work on deconstruction of meaning to legal theory).

155 See Land Adjudication Act, (2012) Cap. 284 s 26A, http://faolex.fao.org/docs/pdf/ken62433.pdf [https://perma.cc/AMD3-6XSE] (demonstrating that at the time of first registration, the Land Adjudication Act requires Adjudication Officers to record leases and rights of occupation recognized 
legal title arises from registration rather than the transaction creates the brightest of bright-line rules: registered interests override unregistered interests, and information about registered interests lies in a public register. In theory, therefore, Torrens law provides optimal reductions in transaction and information costs for all resource participants - creating Demsetzian incentives to transition to Torrens law in order to reduce the private costs of property and the social costs of resource competition.

The dense relational webs of property may impose collective constraints on cost-minimizing incentives to transition to law, because of customary obligations to family, neighbors or a local community. Kenya provides an example as relational aspects of property in Kenya reflect embedded social obligations that are quite distinct from the bright-line rules of Torrens law. For example, a survey by Angelique Haugerud found that around $85 \%$ of rural households are constituted by multi-generational family groups, with married sons and unmarried daughters living in homestead arrangements involving separated housing. In a survey by H.W. Okoth-Ogendo of two districts in western Kenya, over $95 \%$ of respondents stated they had acquired land through lineage or extended family inheritance mechanisms. In one district, $87 \%$ of respondents agreed it was "inconceivable" that a registered proprietor would attempt to expel lineage members from the land, and only $4 \%$ stated that they would move willingly in the event of any such attempt at expulsion. In the other survey district, 28\% agreed that expulsion was inconceivable, and 55\% stated they would "demand their share" in the event of expulsion. 156 Yet, in all cases, while there are deep-seated perceptions that lineage members have entitlements to land, the effect of Torrens law is that those with unregistered claims to lineage land have no lawful cause of action against registered proprietors in the absence of agreements to occupy, or other bases for personal claims in courts exercising equitable juris-

by customary law in the land titles register); see also Simon Coldham, The Effect of Registration of Title upon Customary Land Rights in Kenya, 22(2) J. AFR. L. 91, 100-02 (1978) [hereinafter Coldham, Effect of Registration] (showing that, in practice, there is very little recording of customary interests as year to year tenancies in Kenya due to the time, expense and complexity of determining interests according to customary law).

156 See generally H.W.O. OKOTH-Ogendo, The PeriLs of LAND Tenure ReForm: The CASE OF KenYa, (University of NAIrobi Digital Repository, 1986), http://hdl.handle.net/11295/35689 [https://perma.cc/25D7-G2DW] (investigating the negative impacts of land tenure reform). 
diction.

There is evidence that many, if not most, legal owners of rural land in Kenya do not comply with the mandatory rules of Torrens law, as a result of adherence to social conventions concerning lineage land. For example, the law requires heirs to report the death of a registered proprietor of land to the local chief, who must inform the District Court, which issues a certificate of succession. Certificates of succession are necessary to register changes to registered proprietorship of land under the Registered Land Act. Very few heirs, however, seek to alter the registered proprietorship of land. ${ }^{157}$ Simon Coldham quotes a government officer writing in the early 1960s that over 3000 titles registered in the names of deceased persons had not been the subject of requests for transfer of registration to heirs in Kaimbu District alone. ${ }^{158}$ Coldham further notes that in East Kadianga no more than $3.4 \%$ of deceased estates had been the subject of registered transfer of title. In Gathinga the figure was 21.4\%.159 Over time, the land titles register has lost currency in Kenya as unregistered male heirs of deceased registered proprietors establish their own families, and pass down their own parcels of land to their sons. ${ }^{160}$ In short, Kenyan land law has attempted, but failed, to displace customary succession practises ${ }^{161}-$ a result that is also reported in studies of the Asante in Ghana and the Minangkbau in West Sumatra. ${ }^{162}$

157 See id. at 12 (discussing provisions that should have been included in the Registered Land Act).

158 See Coldham, Land Tenure Reform, supra note 71, at 618 (citing F. D. Homan, Succession to Registered Land in the African Areas of Kenya, II J. ADMIN. OVERSEAS (LONDON) 50).

159 See Coldham, Effect of Registration, supra note 155, at 105 (elaborating on the operations of the land register).

160 See Angelique Haugerud, Land Tenure and Agrarian Change in Kenya, 59(1) ACCEss, CONTROL \& USE OF ResOuRCES IN AFR. AGRIC. 61, 66 (1989) (describing divergences between formal and informal tenure systems).

161 See Registered Land Act, (1963) Cap. 300 s 107, http://kenyalaw.org/kl/fileadmin/pdfdownloads/Acts/RegisteredLandActCap 300.pdf [https://perma.cc/2KKJ-G3VX] (stating that the Registered Land Act preserves the customary law(s) of succession: it seeks to displace the laws to the extent that it requires register changes to the proprietorship of land through prescribed instruments in order to give effect to transfers of legal title).

162 See Sara Berry, The Everyday Politics of Rent-Seeking: Land Allocation on the Outskirts of Kumase, Ghana, in NEgOTIATING PROPERTY IN AFriCA 111, 115 (Kristine Juul \& Christian Lund eds., 2002) ("the law appears to have made only modest inroads into the practise of matrilineal inheritance"). Among the matrilineal Minangkbau of West Sumatra, Franz and Keebet von Benda Beckmann ascribe 
A methodological focus on individual choice-making may explain the Kenya case on the basis of constraints on cognition and information. ${ }^{163}$ Studies in behavioral economics identify the way in which humans frame choices of coordination mechanisms according to familiarity as they are averse to losses, including losses caused by the unfamiliarity of transition to law. ${ }^{164}$ As a result, they may resist or ignore law simply because it is the product of a distant centralist state. They may prefer local coordination mechanisms because of constraints on calculating the benefits of law. Their predictions of behavior may be shaped by membership of a community or group rather than citizenship of a state. Similarly, the internalization of customs as norms, and conventions of behavior, may create pro-social preferences where individuals adopt coordination strategies notwithstanding the net private costs of their actions. ${ }^{165}$ This may involve processes of 'team reasoning', where individuals who self-identify as members of a group attempt to select a focal point because they believe that other participants are likely to select the same focal basis for coordinated behavior. ${ }^{166}$ All these constrained acts of individual choice form part of fragmented property outcomes where they involve decisions not to submit or resort to law.

low rates of registration of individual titles to land to the potential for conflict with the inheritance rights of sub-lineage members, as registration implies decisions to allocate the assets of a deceased estate to children only. For more information, see Franz \& Keebet von Benda-Beckmann, Struggles over Communal Property Rights and Law Minangkabau, West Sumatra, (Max Planck Institute for Social Anthropology Working Paper No. 64, 2004), http://www.eth.mpg.de/pubs/wps/pdf/mpi-eth-working-paper-0064.pdf

[https://perma.cc/GE9X-CYE8].

163 See generally Christine Jolls et al., A Behavioral Approach to Law and Economics, 50 STAN. L. REV. 1471 (1998) (providing a normative analysis of how and when the legal system respects people's choices).

164 See Ostrom, supra note 152, at 208-209 (applying the work of Daniel Kahneman and Amos Tversky providing a discussion in relation to resource governance).

165 See generally Jeffrey P. Carpenter, Negotiating in the Commons: Incorporating Field and Experimental Evidence into a Theory of Local Collective Action, 156 J. INST. \& THEORETICAL ECON., 661 (2000) (offering a view of how studies of law and economics can be improved by increased attention to insights about human behavior).

166 See generally Nicholas Bardsley, et al., Explaining Focal Points: Cognitive Hierarchy Theory versus Team Reasoning, 120 ECON. J. 40 (2010) (reporting that coordinated behavior is the result of group members' reasoning based on their common beliefs and the individuals' pre-reflective inclincations towards the relevant strategies). 
Anthropological studies highlight the fact that decisions to adopt group custom help to construct social identity within a group, while also reinforcing the legitimacy of the custom itself. 167 Custom implicates processes of legitimation - the way in which a practice becomes accepted as "customary."168 Custom may develop legitimacy not only through repetition or past practice, but through cultural processes of habituation - the application of values, beliefs and reasoning characteristic of a particular social group. ${ }^{169}$ Habituation tends to occur within a social field - a structural space for repeat human interaction. ${ }^{170}$ The language, ritual and myth that create a social field also shape the emergence of shared expectations of behavior. As a result, the analytical techniques of anthropologythe study of myth, ritual and language - provide insights into fragmented property outcomes when the state-centric narratives of land law fail to displace the habituation processes of sub-state property systems. ${ }^{171}$

Multi-disciplinary perspectives are necessary to explain interactions among custom and law in multi-scale property systems. The economic literature on small group property systems highlights the potential for exit as a result of demographic growth and increased sale or lease of land to outsiders. ${ }^{172}$ In similar vein, Abraham Bell

167 See generally John W Meyer \& Brian Rowan, Institutionalized Organizations: Formal Structure as Myth and Ceremony, 83 AM. J. Soc. 340 (1977) (establishing that when formal organizational structures become isomorphic with the myths of the of the institutional environment, a group logic of confidence and good faith is employed in order to maintain legitimacy).

168 For a leading sociological discussion, see generally Lynne G Zucker, The Role of Institutionalization in Cultural Persistence, 42 AM. SoC. REV. 726 (1977).

169 For sociological studies that analyze habituation as a function of collective processes rather than individual agency, see generally ANTHONY GIDDENS, THE CONSTITUTION OF SOCIETY (1984) (setting out a structuration theory of institutions); see also MARY DOUGLAS, How INSTITUTIONS THINK (1986) (describing processes of naturalizing institutions).

170 See, e.g., Deborah ReEd-DANAhay, Locating Bourdieu (Dephne Berdahl, et al., eds., 2005) (discussing Bourdieu's use of social field concepts).

171 See Boaventura de Sousa Santos, Law: A Map of Misreading. Toward a Postmodern Conception of Law, 14 J. L. \& Soc'Y 279 (1987) (setting out a theory of structural spaces through which law is negotiated); see also Sally Falk Moore, Law and Social Change: The Semi-Autonomous Social Field as an Appropriate Subject of Study, 7 L. \& SOC'Y REV. 719 (1972-1973) (describing the semi-autonomous social fields that govern the relationship between legal change and social change).

172 Self-governing systems require information flows to induce cooperation through the threat of withdrawal of cooperation. Other members of a group must be aware of a transgression such as non-compliance with property in order to refuse to cooperate. Conversely, a potential transgressor will take into account the 
and Gideon Parchomovsky highlight the network effects of law the more people following law the greater the costs of extra-legal arrangements. ${ }^{173}$ Yet, there remains a puzzle of customary persistence, even in circumstances where individual cost/benefit calculations favor submission or resort to law. Cases of customary persistence require circumstances where neither the state nor de jure landholders engage in coercive enforcement of law - as in the agricultural and forest area cases discussed in Part I above. In these types of circumstances, Bell and Parchomovsky apply cost/benefit perspectives to argue that extra-legal property regimes may persist inter alia where the costs of legal conformity are too high. ${ }^{174}$ The Kenyan case further suggests that disciplinary perspectives such as anthropology are required to explain the habituation processes that shape the preferences, perceptions and cost/benefit pay-offs of individual decisions not to conform with law.

\subsection{Transitions to Law}

Richard McAdams and others highlight the expressive benefits of law-the potential for the public expression of law to ensure transition to focal points selected or created by law. ${ }^{175}$ Law may

likelihood of information about the transgression being transmitted to other members of the group or network. As new members join a group there will be marginal increases in the costs of information where new members lack the information connections of long-term members. Increased dealings with outsiders also lead to marginal increases in the costs of processing information on reputation for cooperation or honesty. See Dixit, supra note 135, at 73-4; see also MUELLER supra note 83, at 264-5, 278-9 (providing a discussion).

173 See generally Abraham Bell \& Gideon Parchomovsky, Property Lost in Translation, 80 U. CHI. L. REV. 514 (2013) (exploring the relationship between localized and state property systems).

$174 I d$. at 520-21. The other explanations for persistence of extra-legal arrangements are also based on cost/benefit analysis (i.e. that interest groups form to maintain the extra-legal regime, or that political incentives create conscious subsidization of costly extra-legal arrangements).

175 See generally Richard H. McAdams, A Focal Point Theory of Expressive Law, 86 VA. L. REV. 1649 (2000), (contending that when individuals need to coordinate, law works to make one equilibrium "focal" and thereby creates expectations that others will play the strategy associated with that equilibrium); see also Robert Cooter, Expressive Law and Economics, 27 J. OF LEGAL STUD. 585 (1998) (developing an expressive theory of the law, in which law can tip a system of social norms into a new equilibrium by expressing social values); see also Dhammika Dharmapala \& Richard H. McAdams, The Condorcet Jury Theorem and the Expressive Function of 
have reputational and informational advantages that facilitate altered expectations of behavior without the need for coercion. The presence of an alternative focal point - selected or created by law creates a fear of negative payoffs: what if other players switch to the new strategy? 176 Once a critical mass of players switch strategies, doubts as to the validity of past experience become selfreinforcing. The converse holds true as well. Where law lacks reputational or informational advantages, past experience of compliance with a focal point such as possession or custom may continue to provide a guide to future behavior notwithstanding law. At local scales of interaction, a critical mass of property users, transactors and potential violators may avoid transitions to law not only because the state is unable or unwilling to enforce law, but because of a lack of familiarity with law, or an absence of belief in the reputational effects of law.

Property participants may not accept specific law as a basis for property coordination because of a lack of knowledge about the consequences of law. Yet, they may accept the idea of state legal order - that lawful decisions of the state provide a basis for property coordination notwithstanding the absence of informational clarity about the law itself. 177 This insight highlights the comparative significance of the state for transitions to law. There may be circumstances where even the idea of state legal order is not a shared basis

Law: A Theory of Informative Law, 5(1) AM. L. \& ECON. REV. 1 - 31 (2003) (arguing that legislation can generate compliance expressively, independently of deterrence); see also Jonathan R. Hay \& Andrei Shleifer, Private Enforcement of Public Laws: A Theory of Legal Reform, 88(2) GOV'T IN TRANSITION 398 (1998) (discussing how the legal system can be the key to institutional reform in governments in transition); see also Richard H. McAdams, An Attitudinal Theory of Expressive Law, 79 OR. L. REV. 339 (2000) (theorizing that law changes behavior by signaling the underlying attitudes of a community or society).

176 For example, a player with hawk strategy may find other players adopting hawk strategies because of anticipated payoffs under a new law. Conversely, a player with a dove strategy may contemplate adoption of a hawk strategy to anticipate dove strategies by other players. Individual participants have incentives to transition to the new focal point when they anticipate that losses created by a failure to change strategy are greater than the distributional losses of the change of strategy.

177 See Nicholas Almendares \& Dimitri Landa, Strategic Coordination and the Law, 26 LAW \& PHIL. 501, 528 (2007) ("In coordinating on a particular set of legal and political institutions whose constitutionally sanctioned operation defines 'the rule of law, citizens are, in effect, coordinating on regarding as legitimate the governance decisions."). 
for expectations of behavior. ${ }^{178}$ Potential examples include states imposed through colonization or invasion, or states affected by perceptions of illegitimacy or endemic corruption. In these cases, the state is not a stable fundamental of social organization. ${ }^{179}$ Its citizens may identify themselves as members of sub-groups, distinguished by language, geography, or ethnicity rather than members of a legitimate constitutional order. ${ }^{180}$ As a result, the capacity of law to select or create new focal points for property coordination not only involves habituation processes within groups, but structural variables associated with the state itself. These variables include the circumstances of state creation, the quality and accessibility of its services, and the strength of its "rule of law" legitimacy. The following case study of Cambodia provides a contemporary illustration.

\subsubsection{State Title to Land in Cambodia}

Cambodia's Land Law of 2001 situates the state at the apex of a hierarchical system of proprietary rights to land. First, it creates a default rule of state title to land-land that belongs to no one belongs to the state. Second, it establishes the state as the allodial source of ownership rights to land-all ownership rights derive from or through the state. After the genocide of Khmer Rouge rule, the Land Law constructs the state as a Westphalian entity with sovereign authority over territory. At the same time, it overlays local

\footnotetext{
178 See, e.g., Olivier Roy, Development and Political Legitimacy: The Cases of Iraq and Afghanistan, 4 CONFLICT SECUR. DeV. 167, 171 (2004). (discussing the challenge to State-building of tribe and family-based loyalties that exist "below the State level"); see also Katherine B. Carroll, Tribal Law and Reconciliation in the New Iraq, 65 MidDLE E. J. 11, 11-29 (2011) (describing the influence of tribal law and custom on conflict resolution in Iraq); see also Mahmud E. Zain, Tribe and Religion in the Sudan, 23 REV. Afr. POL. ECON. 523, 528 (1996) (analyzing the role of tribal categories in the Sudanese polity).

179 For a comprehensive, theoretical overview of state formation and its relationship with property, see Christian Lund, Negotiating Property Institutions: The Symbiosis of Property and Authority in Africa, in NegOtIATING PROPERTY IN AFricA, 11 (2002).

180 For a discussion on circumstances of state collapse, see William Zartman, Introduction: Posing the Problem of State Collapse, in COLLAPSED STATES: THE DisinTEGRATION AND RESTORATION OF LEgITIMATE AutHORITY 1, 5 (1995) ("As a symbol of identity, [the State] has lost its power of conferring a name on its people and a meaning to their social action.").
} 
property orders based primarily on expectations of respect for possession. While the law recognizes possession as a basis for ownership, it excludes state land from lawful acts of possession, including ownership claims based on acquisitive prescription under the Civil Code or "special acquisitive possession" under the Land Law. The result is a high degree of fragmentation as norms of possession remain resilient notwithstanding that the state claims large areas of land subject to acts of possession as state land.

Under the 2001 law, a Cambodian citizen may apply for ownership rights to land on the basis of a rule of special acquisitive possession-five years' continuous possession of land prior to August 30, 2001.181 Yet, the law also provides that land subject to special acquisitive possession must be capable of lawful possession. There is no lawful possession of land that is the "public property" of the state, which includes areas on the banks of lakes or rivers. ${ }^{182}$ Moreover, after August 30, 2001, there is no lawful possession of land that is the "private property" of the state, which is a default category that includes all land owned by the state that is not state public property. These provisions also apply to acquisitive prescription under the Civil Code. ${ }^{183}$ The 2001 law, then, establishes state title as a default: the state is the owner of land in Cambodia that has not been allocated to private applicants through grant or as a result of special acquisitive possession. ${ }^{184}$ Government officials may desig-

\footnotetext{
181 Land Law, arts. 30, 32, 38 (2001) (Cambodia).

$182 I d$., art. 16

183 Civil Code art. 162(2) (Cambodia). 162.

Prescriptive acquisition of ownership over immovable
}

(1) A person who peacefully and openly possesses an immovable for a period of 20 years with the intention of ownership shall acquire ownership thereof.

(2) A person who peacefully and openly possesses an immovable for a period of 10 years with the intention of ownership shall acquire ownership thereof if the possession commenced in good

faith and without negligence.

(3) Neither paragraph (1) or (2) shall apply to any immovable property belonging to the state, regardless of its kind.

184 Land Law, art. 12 (2001) (Cambodia). 
nate state land simply by declaring that an area of land has not been occupied in accordance with the rule of special acquisitive possession.

In principle, Cambodia's Land Law provides incentives to transition to law through a Torrens system of title registration. Successful applicants for ownership on the basis of acquisitive prescription or special adverse possession receive a title that defeats unregistered claims in the absence of fraud by the registered proprietor. ${ }^{185}$ However, while approximately 1.2 million land titles were registered from 2002 to 2009 under a World Bank-funded program (LMAP), ${ }^{186}$ there has been incomplete coverage and exclusion of large numbers of landholders as a result of extensive government claims of state land, particularly in urban areas. For example, a 2009 survey of thirty-nine Phnom Penh communes titled under LMAP identified ten communities with 2,000 families that received land titles while 100 communities housing more than 10,000 families did not receive titles. The success rate for households claiming title was a strikingly low twenty percent. A sample of twelve communities that did not receive titles concluded that eight had not been subject to titling simply because government officials had asserted that the land was state property. ${ }^{187}$ Another LMAP review of 8,448 households in titling areas concluded that "a significant proportion" of land disputes in Cambodia concerned State claims over currently occupied land, and that "in a number of these cases" the residents had good faith claims to title as lawful long-term possessors. ${ }^{188}$

The state claims approximately eighty percent of land in Cam-

\footnotetext{
185 See Land Law, art. 65 (2001) ("The transfer of ownership can be enforceable as against third parties only if the contract of sale of immovable property is made in writing in the authentic form drawn up by the competent authority and registered with the Cadastral Registry Unit. The contract of sale itself is not [sufficient] for the transfer of the ownership of the subject matter."); see also CIVIL CODE arts. 134, 135 (Cambodia) (respectively limiting assertion of ownership against third parties to registered rights, and requiring registration for transfers of rights to have legal effect).

186 WORLD BANK, IMPLEMENTATION COMPLETION AND RESUlTS REPORT: LAND MANAGEMENT AND ADMINISTRATION PROJECT XII (2011).

187 Id. at xiiv.

188 See Mohammed A. BeKHeChi \& Lars Lund, CAMbodia Land Management AND Administration Project: ENHANCED REVIEW RePORT (2009) (documenting findings about the implementation of the LMAP and the circumstances on the ground surrounding occupied land and evictions).
} 
bodia as state land. ${ }^{189}$ It has granted economic land concessions of over fifty percent or more of all arable land, primarily to commercial agribusiness interests, but also for commercial logging, mining, hydro-electric dams, special economic zones, and tourist resorts. 190 In the capital, Phnom Penh, there are more than 100,000 slum dwellers spread over 511 informal settlements. ${ }^{191}$ Some informal occupants have been in residence for decades. ${ }^{192}$ There are widespread perceptions of de facto land ownership based on possession notwithstanding that Torrens rules limit legal ownership to registered title only. ${ }^{193}$ At times, there is a reluctance to accept offers of relocation or compensation by the state because of a perception of the unreliability of state promises. There is a lack of serviced private land in urban or peri-urban areas for poor households to obtain lawful residential title. As is common with other informal environments, there is regular use of documentation witnessed or granted by local government officials as a basis for informal markets in land. Even those with registered title rarely register subsequent transactions or transfers of rights, as mandated by law, because of widespread preferences for local mechanisms of land administration. 194

Few landholders in Cambodia appear to coordinate property re-

189 Cambodia - Land Management and Administration Project, 6, WORLD BANK, http:/ / documents.worldbank.org/curated/en/643811468770346842/CambodiaLand-Management-and-Administration-Project [https://perma.cc/4NLF-TFFP] (2002).

190 See The Great Cambodia Giveaway: Concessions Over Time, LICADHO, http://www.licadho-cambodia.org/concession_timelapse

[https:// perma.cc/P69L-M6XN] (illustrating Cambodia's "land grabbing crisis" through a timeline map showing land concessions granted by the Cambodian government from 1993 to 2013). For further references on agrarian "land grabs" in Cambodia, see CAMBOdian Human Rights ACTION COMM., LOSING GROUND: FORCED EVICTIONS AND INTIMIDATION IN CAMBODIA 65 (2009).

191 See Chhay Channyda \& Abby Seiff, Phnom Penh's slums swell in 2012, THE PHNOM PENH POST, http://www.phnompenhpost.com/national/phnompenh\%E2\%80\%99s-slums-swell-2012 (Feb. 19, 2013). [https://perma.cc/RR6WRQ4A] (placing the growth of the cities' slums in the context of a lack of titles in the city and land disputes in rural areas); see also PIERRE FALLAVIER, URBAN SLUMS REPORT: THE CASE OF PHNOM PENH, CAMBODIA (2003) (setting forth the history of and statistics concerning slums in Phnom Penh).

192 Channyda \& Seiff, supra note 191.

193 See UN-HABitAT, CHALLENGE OF SLUMS, supra note 16, at 222 (estimating that around $75 \%$ of unregistered landholders in Phnom Penh regard themselves as owners of the land).

194 GRIMSDITCH \& HENDERSON, supra note 78. 
lations on the basis of law. One study identified only a minority that understood the need to apply for ownership rights on the basis of possession prior to 2001.195 Many believed incorrectly that obtaining a receipt from local commune officials acknowledging their possession of land was sufficient evidence of legal rights of ownership. ${ }^{196}$ A majority of landholders also invest in sales and other documentation signed or witnessed by local commune chiefs. As a general rule, landholders are not even aware that their land is claimed as state land until local government officials announce a development project, or commercial representatives begin to erect fencing and other notifications of their economic land concession. ${ }^{197}$ In a context of broad-based perceptions of corruption and illegitimate land grabs by state actors, there is scant evidence of a social consensus that the state is the allodial source of title to land. Yet there are resilient social beliefs that long-term possession creates an entitlement to land. ${ }^{198}$ Notably, these beliefs provide the basis for property sub-systems both in circumstances of illegality, where land is classified as state land, and where lawful landholders decline to follow mandatory rules of title registration.

Cambodia challenges Demsetzian assumptions that hard-edged, state-centric land law induces adoption of law as a basis for property relations where it provides optimal reductions in the transaction and information costs of property. ${ }^{199}$ Cases from Cambodia illustrate a range of property strategies despite bright-line law, not simply resort to law or efficient substitution of norms for law, but also selective enforcement of law by state actors and acts of resistance,

\footnotetext{
195 Adler et al., Legal Pluralism AND EQuity: SOME REFLECTIONS ON LAND REFORM IN CAMBODiA 69, at 56 (2008).

196 See Chi Mgbako et al., Forced Evictions and Resettlement in Cambodia: Case Studies from Phnom Penh 9 WASH. UNIV. Global Stud. L. Rev. 39, 46 (2010) (“[D]ue to poor rights education among Cambodian communities, families who are eligible for legal ownership after five years of possession are often unaware of the procedure for claiming this right.").

197 See Collective Grievances over Land in Cambodia: A Study of Five Provinces 15, WORLD BANK (2004) [hereinafter WORLD BANK, COLLECTIVE GRIEVANCES] (noting a commune counsellor's comment that the anger of villagers over the grant of an economic land concession for a term of 25 years resulted from a failure to communicate or give notice of the grant).

198 Id. at 31.

199 See Eduardo Moisés Peñalver \& Sonia K. Katyal, Property Outlaws, 155 U. PA. LAW. REV. 1095 (2007) (noting the interrelationship between the hard-edged character of property rules and acts of protest or resistance against property regimes).
} 
disengagement, and reluctant submission by private landholders. ${ }^{200}$ Some landholders submit to claims of state title as a result of fears of conflict with powerful state actors. ${ }^{201}$ Others engage in acts of resistance through symbolic broadcasts of a capacity for violencea strategy designed to induce intervention by a powerful administrative decision-maker. ${ }^{202}$ For their part, some administrative decisionmakers attempt situational resolution of conflict over land through decisions not to enforce claims of state title. ${ }^{203}$ Other local government actors participate in hybridized mechanisms of property coordination based both on physical possession and documentary receipts evidencing possession. All these examples highlight strategic pathways for negotiating property where there are fragmented sources of public authority and social legitimation. In this sense, they support a key finding of anthropological studies of legal pluralism - that property system fragmentation involves the cooption and hybridization of coordination mechanisms across multiple scales of private/public interaction. ${ }^{204}$

200 For examples, see WORLD BANK, COLLECTIVE GRIEVANCES, supra note 197.

201 Id. at 16. See also Mgbako et al., supra note 196, at 53-4, 56 (detailing how one community struggled to navigate the judiciary's resistance to its concerns and a lack of government transparency).

202 See WORLD BANK, COLLECTIVE GRIEVANCES, supra note 197, at 31 (describing two cases of resistance to claims of state land-involving projects for infrastructure (a reservoir) and commercial agriculture (irrigation)).

203 See id. at 31 (In both cases described in the World Bank report, the provincial Governor intervened to suspend the proposed project. Yet, the state did not withdraw its claims of state title to land, leaving the landholders in a state of unenforced illegality).

204 See, e.g., Keebet von Benda-Beckmann, Forum Shopping and Shopping Forums, Dispute Processing in a Minangkabau Village in North Sumatra, 19 J. LEGAL PLURALISM 117 (1981) (describing hybridized private/public competition to resolve land disputes in West Sumatra); see also Camilla Toulmin et al., THE DynAmics of RESOURCE TENURE IN WeSt AFriCA 1, 11 (C. Toulmin et al. eds., 2002) ("IIn Africa], tenure has remained embedded in social networks despite the intervention of colonial and post-independence governments . . . We then see a network of players forming around the state administration, seeking preferential access and treatment, and making the land issue increasingly politicised."). The studies identify mutually constitutive interactions between private property and public authority: the mere act of authorizing certain rights to land constitutes a process of recognizing the authority of the decisionmaker. See, e.g., Franz von Benda-Beckmann, Scapegoat and Magic Charm: Law in Development Theory and Practice, in AN ANTHROPOlOGICAL CRITIQUe OF Development: ThE GROWTH OF IGNORANCE 127 - 30 (Mark Hobart ed., 1993) (discussing the methodological implications of applying certain models of law to a range of interaction settings). For an overview of anthropological literature on relations between property and authority, see Lund, supra note 131. 


\subsection{The Paths of Property Systems}

The case studies of California, East Timor, Kenya, and Cambodia provide insights into the comparative paths of property systems. Some property systems appear to align coordination mechanisms at spatial scales of interaction so as to reduce the total costs of access to resources. A critical mass of resource users, transactors and potential violators coordinate property relations on the basis of law, either because law aligns with local coordination mechanisms, or because law or the state induces alterations in equilibrium strategies of property coordination. Other property systems experience misalignments among coordination mechanisms where law attempts, but fails, to induce a critical mass of resource users, transactors or potential violators to alter coordination strategies based on focal points outside of law. The implication is that transitions to lawbased focal points for property coordination are critical junctures in the evolution of property systems.

The Cambodia case highlights the historic significance of European-derived land laws that linked property with state sovereignty. Key principles of European land law - that ownership derives from or through sovereign grant, and that land 'without a master' belongs to the sovereign - were fundamentally disruptive of popular understandings of property in the subject territories of European colonization. ${ }^{205}$ European-derived land law imagines property

\footnotetext{
205 In civil law jurisdictions, the Regalian doctrine (and its equivalents) vested land that was not the subject of statutory grant by the sovereign in the European sovereign. For example, in the Spanish Philippines, the Recopilacion de Leyes de las Indias vested all land "held without proper and true deed of grant" in the Spanish Crown. Except for land reserved for public and common use, and after "distributing to the natives what may be necessary for tillage and pasturage," all land was "free and unencumbered" for disposal by the Crown. In the Dutch East Indies the 1870 Agrarische Besluit (Royal Agrarian Decree) stated that all land not held under ownership (eigendom) rights fell within the domain of the State (Art. 1). In the common law, "native" rights to land were not classified as estates held of the Crown at the time of sovereign acquisition. Unless the land was deemed terra nullius, "native" rights to land were classified as a permissive occupancy, or a personal right of usufruct, terminable at the will of the Crown and alienable to the Crown only. For examples, see Tee-Hit-Ton Indians v. U.S., 348 U.S. 279, 281 (1955); Calder v. Att'y Gen. of B.C., [1973] S.C.R. 313, 352- 353 (Can.); St. Catherine's Milling [1888] 14 App. Cas. 46, 54 (Can.); Sec'y of State for India v. Sardar Rustam Khan [1941] AC 356, 371 (PC); Vajesingji Joravarsingji v. Sec'y of State for India [1924] LR 51 Ind Ap 357, 360 (PC); Amodu Tijani v. Sec'y, S. Nigeria [1921] 2 AC 399, 403 (PC).
} 
in abstract spatial terms, arranged by neatly stacked hierarchies of rights, and subject to overarching notions of sovereign authority. Yet, in too many contemporary contexts, the bright-line visions of conventional land law do not match the enduring reality of informal, semi-formal or illegal property sub-systems. This article has identified a range of reasons for the emergence of this phenomenon of property system fragmentation-not only the distributional losses of law and the coercive capacity of the state, but also the social embeddedness of possession and custom, and the salience and legitimacy of state legal order.

\section{CONCLUSION}

The analysis has normative implications for the design of law. In standard economic analysis, law may provide optimal reductions in the information and exchange costs of property, and the social costs of resource competition, through standardized packages of entitlements derived from or through the state. The focus on information and exchange costs lies behind land laws that (1) mandate registration of titles or transactions, and (2) limit freehold proprietary entitlements to titles derived from or through the state. In relation to exchange, the hard-edged character of a rule of ownershipas a standard package of entitlements derived from or through the state-facilitates valuation of entitlements, markets for capital and credit, and gains from trade. In relation to information, the registration of titles or transactions by the state reduces the costs of determining what is being exchanged. Merrill and Smith, in particular, highlight the information benefits of standardized property rules and entitlements. The ex ante identification of permitted and proscribed behavior reduces the costs of identifying, delineating, and understanding the entitlement subject to exchange. ${ }^{206}$

The analysis suggests that land laws with a focus on information and exchange costs reduce the total costs of competition for resources where there are expectations of legal enforcement by the state, or patterns of property coordination on the basis of law or le-

206 See Thomas W. Merrill \& Henry E. Smith, Optimal Standardization in the Law of Property: The Numerus Clausus Principle, 110 YALE L.J. 34 (2000) (discussing how land laws may take on elements of "fuzziness" or complexity where gains in transactional efficiency outweigh increases in the cost of information). 
gal order. But where there are no expectations of enforcement by the state, and fragmented mechanisms for property coordination, land laws that focus on information and exchange costs may increase the total costs of resource competition by increasing the costs of compliance with property across multiple scales of resource interaction. This suggests, in turn, that there is no "one-size-fits-all" property law for different social contexts. The economic effects of law turn not only on information and exchange costs but on context-specific conditions of property coordination. Chronic circumstances of property system fragmentation thus support the conclusion that a failure to adapt legal rules so as to support existing mechanisms of property coordination may increase the total costs of resource competition, notwithstanding reductions in the costs of exchanging and understanding property. This normative conclusion will be explored in a separate work. 